\title{
DRAFT
}

\section{Compatibility Determination: \\ Considerations for Siting Coastal and Ocean Uses}

July 2009

Prepared by:

The UMass Boston Planning Frameworks Team and

The Massachusetts Ocean Partnership 



\section{ACKNOWLEDGEMENTS}

Contributors:

University of Massachusetts Boston

Urban Harbors Institute: Jack Wiggin, Kristin Uiterwyk, Steve Bliven, Dan Hellin

Environmental, Earth and Ocean Sciences Department: John Duff

Good Harbor Consulting: Fara Courtney

Provincetown Center for Coastal Studies: Rich Delaney, Pat Hughes

University of Rhode Island Marine Affairs Department: Tracey Morin Dalton

Massachusetts Ocean Partnership: Stephanie Moura, Nicholas Napoli, Kim Starbuck 



\section{GOALS AND PURPOSE}

This draft report is one of several prepared under contract to the Massachusetts Ocean Partnership (MOP) to support the Massachusetts Executive Office of Energy and Environmental Affairs (EEA) in its development of the integrated coastal ocean management plan mandated by the MA Oceans Act of 2008. Among other requirements, the Oceans Act states that the plan shall "identify appropriate locations and performance standards for activities, uses and facilities allowed under sections 15 and 16 of chapter $132 \mathrm{~A}^{1}$." To fulfill this requirement, the EOEEA planning team wanted to utilize compatibility determinations as a tool for considering the appropriate locations for activities, uses and facilities relative to one another. This report was prepared for Massachusetts ocean planning purposes but contains information that may be useful to coastal ocean resource managers in other locations.

A compatibility determination is a tool used to consider the impact of particular human uses on other resources and/or uses located or occurring in the same area to better understand their relative compatibility or incompatibility. This draft report contains information that can be used to inform compatibility determinations for certain uses occurring in coastal/ocean locations (i.e. aquaculture, offshore wind energy, etc.) and for certain uses in conjunction with resources (i.e. fish stocks, eelgrass beds, etc.). The analyses can inform spatial and temporal siting decisions and development of performance standards associated with particular uses.

There are a number of ways compatibility determinations may be employed, including (a) the preparation of a management plan requiring decisions to be consistent with that plan's goals, objectives, and policies, and (b) developing a marine spatial plan to identify what can and cannot happen in specific areas (for more information, see "Planning Framework Options for the Massachusetts Ocean Plan" located at www.massoceanpartnership.org).

The compatibility determination information in this report is displayed in the form of A) a compatibility matrix and B) compatibility tables. MOP and its contractors are building off this preliminary work to develop other software-based models and decision support tools to assist with compatibility determinations and the development of performance standards.

\section{A) COMPATIBILITY MATRIX}

One useful application of the compatibility matrix during Massachusetts' ocean planning process was simply to organize information about the potential interactions between different uses and between uses and resources. Developed further, a compatibility matrix tool can also be used to examine issues such as where uses are compatible or incompatible with other uses/resources; where uses may be conditionally compatible with other uses/resources if certain criteria - including temporal considerations - are met; and where compatibility may be linked to a policy component. The draft matrix below is a preliminary snapshot of compatibility planning in Massachusetts. (Nothing in this matrix should be interpreted as the Commonwealth's final compatibility decision with regard to any specific use or resource.)

\footnotetext{
${ }^{1}$ Sections 15 and 16 of Chapter 132A provide a list of prohibited and allowed uses in Massachusetts' ocean sanctuaries. Refer to the General Laws of Massachusetts for more information.
} 
While a matrix such as that shown below is useful to organize information and examine compatibility decisions, a considerable limitation is that it does not enumerate the rationale for each determination of compatible, incompatible, conditionally compatible, etc. Those compatibility decisions may be influenced or determined by many things, including:

- The types of decision support tools/models used (or potentially used);

- Data availability;

- Commonwealth laws and policies; and/or

- Experiences from similar projects elsewhere. 
Draft Compatibility Matrix

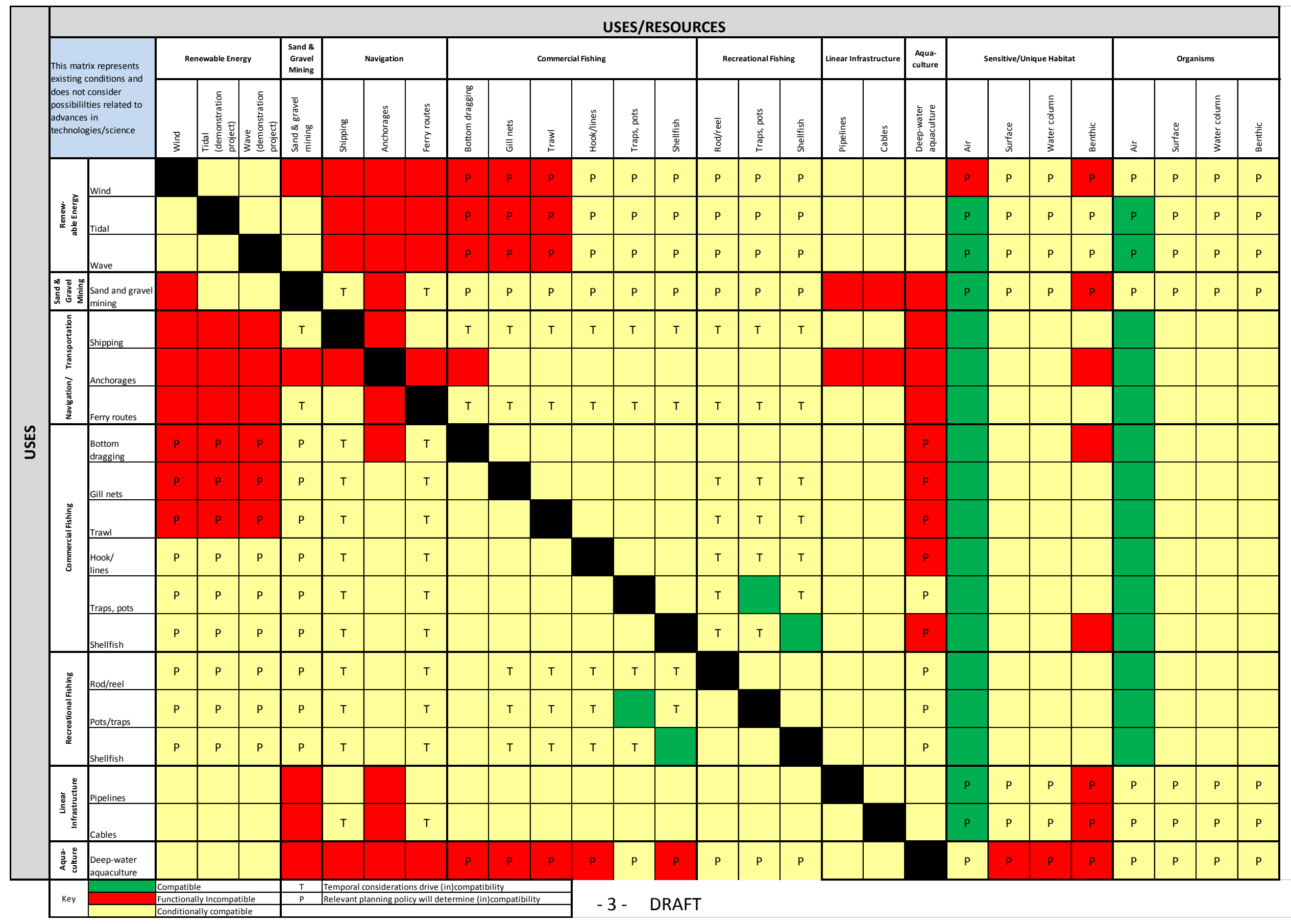




\section{B) COMPATIBILITY TABLES}

As mentioned above, one possible source of information to inform compatibility decisions for ocean uses and resources is to look at experiences from similar projects conducted elsewhere. Massachusetts' ocean planning considered many uses, but because much of the planning area is governed by the Ocean Sanctuaries Act, focused on:

- Offshore wind energy;

- Submarine pipelines;

- Submarine cables;

- Aquaculture (including shellfish and finfish projects); and

- Sand and gravel mining.

Focusing on these specific uses, examples were pulled from the projects listed below and were summarized in the following compatibility tables. The tables identify spatial considerations (impacts of uses or uses and resources occupying the same space at the same time) and temporal considerations (temporary impacts, or impacts that are tied to a specific timeframe), as well as examples of siting standards, compensation requirements, mitigation requirements, and license conditions.

These tables were developed under a tight deadline; therefore research was limited to published and online sources only. Efforts were made to include a wide range of projects from activities having some relevance to Massachusetts. While these tables provide a strong base of information, they are not meant to be comprehensive, and additional research may yield further information for each use. For example, offshore oil and gas extraction is not a priority for Massachusetts waters, therefore the review of aquaculture projects did not include any co-located with oil and gas development, and the tables reflect this gap. Blank cells indicate either a) lack of available information based on the materials reviewed - as in the case of aquaculture and offshore oil and gas - or b) absence of impact a use has on another use or a resource - as in the case of aquaculture and civil aviation.

Though not directly stated in all of the tables, cumulative impacts are an important consideration when siting a project, and may affect siting standards, mitigation requirements, license conditions, and/or compensation required. Cumulative impacts should be considered in situations where (1) the impacts stem from one type of use repeated multiple times or in multiple locations, and/or (2) the impacts stem from different types of uses.

The projects reviewed while creating these tables include:

African Development Bank. (2009). Memorandum: Ghana \& Nigeria: Main One submarine cable environmental and social impact assessment executive summary.

Berrigan, M. Division of Aquaculture, Florida Department of Agriculture and Consumer Services. Personal communication. March 2009.

Boers, M. (2005). Effects of a deep sand extraction pit. Final report of the PUTMOR measurements at the Lowered Dump Site.

BoWind. (2005). Barrow Offshore Wind Farm: Specifications for pre-during and post construction environmental monitoring.

British Columbia Ministry of Agriculture, Food and Fisheries. (2002). BC Salmon Aquaculture Policy.

British Columbia Ministry of Agriculture, Food and Fisheries. Salmon Aquaculture Review's Recommendations. 
British Wind Energy Association. (2007). Investigation of Technical and Operational Effects on Marine Radar Close to Kentish Flats Offshore Wind Farm.

Byrnes, M.R., Ramsey, J.S., Hammer, R.M., Wadman, E.A. (2000). Assessing Potential Environmental Impacts of Offshore Sand and Gravel Mining.

Danish Energy Authority. (2006). Offshore Wind Farms and the Environment: Danish experiences from Horns Rev and Nysted.

Department of Energy Office of Electricity Delivery and Energy Reliability and Bonneville Power Administration. (2007). Port Angeles-Juan de Fuca Transmission Project Draft Environmental Impact Statement.

Dredging News Online: http://www.sandandgravel.com/news/page.asp?v1=8.

Environmental Impacts of Offshore Renewable Energy Development for the Exchange of Information (on behalf of OSPAR): www.environmentalexchange.info.

European Commission. (2005).Concerted Action for Offshore Wind Energy Deployment (COD), Work Package 4: Environmental Issues.

Federal Energy Regulatory Commission. (2008). LNG - Environmental Impact Statements (EISs): FERC Staff issues Final Environmental Impact Statement (FEIS) on the Broadwater LNG Project (Docket Nos. CP06-54-000, et al.).

Fiskeridirektoratet. (2009). Marine Protected Areas webpage: http://www.fiskeridir.no/fiskeridir/english/resource-management/marine-protectedareashttp://www.fiskeridir.no/fiskeridir/english/resource-management/marine-protected-areas.

Florida Department of Agriculture and Consumer Services. Florida's Aquaculture Lease Program.

Florida Department of Environmental Protection. Chapter 18-20: Florida Aquatic Preserves.

Grishin, Nikolai. Environmental Impact Assessment of a Transboundary Pipeline in the Black Sea Region: Legal and environmental aspects.

Lindeboom, H., van Kessel, J.G., and Berkenbosch, L. (2005). Areas with special ecological values on the Dutch Continental Shelf.

Maine Department of Marine Resources. (2009). Findings, Facts, Conclusions of Law, and Decision Bottom Culture of Blue Mussels.

Martin McCarthy. Sustainable Energy Ireland - Renewable Energy Information Office. Personal Communication. March 2009.

Minerals Management Service. (2009).Cape Wind FEIS, Table E-1: Summary of Impacts.

Minerals Management Service. (2008).Guidelines for Obtaining Sand, Gravel and Other Non-Energy Mineral Resources for the Federal Outer Continental Shelf: $3^{\text {rd }}$ Edition.

Minerals Management Service. Negotiated Noncompetitive Lease for Sand, Gravel and Shell Resources on the Outer Continental Shelf: Lease \# OCS-G-23707.

Minerals Management Service. Negotiated Noncompetitive Lease for Sand, Gravel and Shell Resources on the Outer Continental Shelf: Myrtle Beach storm damage reduction project (REACH 2) lease stipulations.

Ministry of Agriculture and Lands. (2007). Open Bay Decision. 
Nord Stream. (2009). Nord Stream Environmental Impact Assessment (EIA) Documentation for Consultation under the Espoo Convention.

Roth, E.M., Verhoef, L.A., Dingenouts, M.W.L. (2004). Concerted Action for Offshore Wind Energy Deployment: Overview of environmental impacts of offshore wind energy.

Sandpit. (2009). Website on dredging regulations: http://sandpit.wldelft.nl/workpage/right/wp2/dredging_regulation_table.htm

URS Corporation. (2006). Final Environmental Impact Report for the Proposed Trans Bay Cable Project: Executive summary.

Warwick Energy. (2002). Barrow Offshore Wind Farm: Non technical Summary.

White Consultants. (2009). Seascape Study (working paper), Offshore Energy Strategic Environmental Assessment (SEA). 
UMass Boston Planning Team, May 2009. This table presents information from a number of international projects. This table should only be used as an initial guide. Additional research would be necessary to identify actual spatial and temporal considerations, standards, conditions, compensations, and mitigation measures for a specific project. This document does not represent positions or conclusions of the preparers, MOP, or EOEEA.

In addition to the information contained in this table, there are some fundamental conditions to consider when siting any type of aquaculture project. They include:

- Appropriate growing conditions (i.e. size, water circulation, substrate, storm exposure, temperature, salinity, dissolved oxygen, currents, hydrology, waves, shoreline stability, snowfall, freeze-over, freshwater availability, predators, plankton blooms, water quality)

- Consistent with applicable planning goals and objectives

\begin{tabular}{|c|c|c|c|c|c|}
\hline & & $\begin{array}{c}\text { POTENTIAL } \\
\text { SPATIAL } \\
\text { CONSIDERATIONS } \\
\text { (May be limited to } \\
\text { the duration of the } \\
\text { project) }\end{array}$ & $\begin{array}{l}\text { POTENTIAL } \\
\text { TEMPORAL } \\
\text { CONSIDERATIONS } \\
\text { (May be limited to } \\
\text { the duration of the } \\
\text { project) }\end{array}$ & $\begin{array}{l}\text { EXAMPLES OF SITING } \\
\text { STANDARDS }\end{array}$ & $\begin{array}{c}\text { EXAMPLES OF } \\
\text { COMPENSATION/MITIGATION/CONDITIONS }\end{array}$ \\
\hline \multirow{2}{*}{ 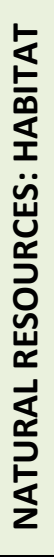 } & Habitat: Air & $\begin{array}{l}\text { Proximity to } \\
\text { important bird } \\
\text { habitat; consistency } \\
\text { with protected } \\
\text { areas' goals }\end{array}$ & & $\begin{array}{l}\text { Project not allowed within } 1 \mathrm{~km} \text { from } \\
\text { existing or approved proposals for } \\
\text { ecological reserves; must be at least } \\
1 \mathrm{~km} \text { from existing or approved } \\
\text { proposals for ecological reserves } \\
<1000 \mathrm{ha}\end{array}$ & $\begin{array}{l}\text { Vessels muffled to reduce noise; lights not used } \\
\text { for any of the aquaculture operation; lessees } \\
\text { must comply with BMP manual and conduct } \\
\text { annual compliance inspections; required criteria } \\
\text { relating to color, height, shape, and mass; lease } \\
\text { will not result in an "unreasonable" impact from } \\
\text { noise or lights at the boundary of the lease site }\end{array}$ \\
\hline & $\begin{array}{l}\text { Habitat: } \\
\text { Surface }\end{array}$ & $\begin{array}{l}\text { Impact to essential } \\
\text { or significant } \\
\text { habitats; } \\
\text { consistency with } \\
\text { protected areas' } \\
\text { goals }\end{array}$ & & $\begin{array}{l}\text { Project not allowed within } 1 \mathrm{~km} \text { from } \\
\text { existing or approved proposals for } \\
\text { ecological reserves; must be at least } \\
1 \mathrm{~km} \text { from existing or approved } \\
\text { proposals for ecological reserves } \\
<1000 \mathrm{ha}\end{array}$ & $\begin{array}{l}\text { Lessees must comply with BMP manual and } \\
\text { conduct annual compliance inspections; required } \\
\text { criteria relating to color, height, shape, and mass; } \\
\text { lease will not result in an "unreasonable" impact } \\
\text { from noise or lights at the boundary of the lease } \\
\text { site }\end{array}$ \\
\hline
\end{tabular}




\begin{tabular}{|c|c|c|c|c|}
\hline & $\begin{array}{l}\text { Habitat: Water } \\
\text { Column }\end{array}$ & $\begin{array}{l}\text { Impact to essential } \\
\text { or significant } \\
\text { habitats; } \\
\text { consistency with } \\
\text { protected areas' } \\
\text { goals; impacts of } \\
\text { food and fish waste }\end{array}$ & $\begin{array}{l}\text { Sites must be outside manatee } \\
\text { protection and speed zones; sites } \\
\text { must be located in areas with } \\
\text { adequate water circulation and } \\
\text { mixing patterns to provide food and } \\
\text { remove waste; sites often sited in } \\
\text { state's aquatic reserves because of } \\
\text { water quality requirements; } \\
\text { aquaculture activities are allowed } \\
\text { only in approved and conditionally } \\
\text { approved waters; sites must be } 300 \\
\text { m from inter-tidal shellfish beds that } \\
\text { are exposed to water flow from a } \\
\text { salmon farm and which have regular } \\
\text { or traditional use from First Nations, } \\
\text { recreational, or commercial fisheries; } \\
\text { must be at least } 1 \text { km from existing } \\
\text { or approved proposals for ecological } \\
\text { reserves <1000 ha; ban on } \\
\text { aquaculture in certain areas }\end{array}$ & $\begin{array}{l}\text { Water quality monitoring and reporting; lessees } \\
\text { must comply with BMP manual and conduct } \\
\text { annual compliance inspections; required criteria } \\
\text { relating to color, height, shape, and mass; lease } \\
\text { will not result in an "unreasonable" impact from } \\
\text { noise or lights at the boundary of the lease site }\end{array}$ \\
\hline & $\begin{array}{l}\text { Habitat: } \\
\text { Benthic }\end{array}$ & $\begin{array}{l}\text { Threats to seagrass } \\
\text { beds; consistency } \\
\text { with protected } \\
\text { areas' goals; } \\
\text { impacts of food and } \\
\text { fish waste }\end{array}$ & $\begin{array}{l}\text { Sites are in water depths greater } \\
\text { than } 4.5 \mathrm{ft} \text {. in order to avoid seagrass } \\
\text { beds; sites in suitable substrate type } \\
\text { to minimize disturbance and loss of } \\
\text { soft and/or live bottom habitat; must } \\
\text { be at least } 1 \mathrm{~km} \text { from existing or } \\
\text { approved proposals for ecological } \\
\text { reserves }<1000 \text { ha }\end{array}$ & $\begin{array}{l}\text { DEP will monitor benthic conditions. If } \\
\text { conditions change, regulatory action may be } \\
\text { triggered; lessees must comply with BMP manual } \\
\text { and conduct annual compliance inspections; } \\
\text { required criteria relating to color, height, shape, } \\
\text { and mass; lease will not result in an } \\
\text { "unreasonable" impact from noise or lights at the } \\
\text { boundary of the lease site }\end{array}$ \\
\hline 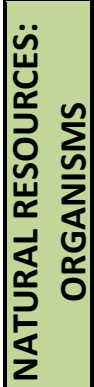 & Organisms: Air & $\begin{array}{l}\text { Threats to } \\
\text { endangered } \\
\text { species; new } \\
\text { feeding/predation } \\
\text { opportunities }\end{array}$ & $\begin{array}{l}\text { Site must be at least } 1 \mathrm{~km} \text { from } \\
\text { existing or approved proposals for } \\
\text { ecological reserves }<1000 \text { ha }\end{array}$ & \\
\hline
\end{tabular}




\begin{tabular}{|c|c|c|c|c|}
\hline & $\begin{array}{l}\text { Organisms: } \\
\text { Surface }\end{array}$ & $\begin{array}{l}\text { Presence of } \\
\text { significant } \\
\text { commercial species; } \\
\text { impact to } \\
\text { flora/fauna; threats } \\
\text { to endangered } \\
\text { species; new } \\
\text { feeding/predation } \\
\text { opportunities; } \\
\text { displacement of } \\
\text { existing species }\end{array}$ & $\begin{array}{l}\text { Site must be at least } 1 \mathrm{~km} \text { from } \\
\text { existing or approved proposals for } \\
\text { ecological reserves }<1000 \text { ha; must } \\
\text { be an appropriate distance from the } \\
\text { areas used extensively by marine } \\
\text { mammals, as determined by DFO and } \\
\text { the province; must be outside } \\
\text { manatee protection and speed zones }\end{array}$ & \\
\hline \multirow{2}{*}{ 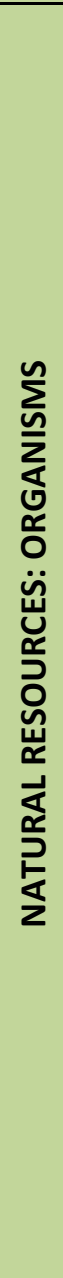 } & $\begin{array}{l}\text { Organisms: } \\
\text { Water Column }\end{array}$ & $\begin{array}{l}\text { Presence of } \\
\text { significant } \\
\text { commercial species; } \\
\text { impact to } \\
\text { flora/fauna; threats } \\
\text { to endangered } \\
\text { species; escape of } \\
\text { penned species; } \\
\text { transmission of } \\
\text { disease to wild } \\
\text { stock; new } \\
\text { feeding/predation } \\
\text { opportunities; } \\
\text { displacement of } \\
\text { existing species }\end{array}$ & $\begin{array}{l}\text { Project not allowed within } 1 \mathrm{~km} \text { of } \\
\text { designated vital, major, or important } \\
\text { herring spawning areas; project not } \\
\text { allowed } 1 \mathrm{~km} \text { from the mouth of a } \\
\text { salmonid-bearing stream determined } \\
\text { as significant in consultation with } \\
\text { DFO and the province; must be at } \\
\text { least } 1 \mathrm{~km} \text { from existing or approved } \\
\text { proposals for ecological reserves } \\
<1000 \text { ha; must be an appropriate } \\
\text { distance from areas of "sensitive fish } \\
\text { habitat", as determined by DFO and } \\
\text { the province; must be an appropriate } \\
\text { distance from the areas used } \\
\text { extensively by marine mammals, as } \\
\text { determined by DFO and the } \\
\text { province; must be outside manatee } \\
\text { protection and speed zones }\end{array}$ & $\begin{array}{l}\text { DEP will monitor dominant species. If conditions } \\
\text { change, regulatory action may be triggered }\end{array}$ \\
\hline & $\begin{array}{l}\text { Organisms: } \\
\text { Benthic }\end{array}$ & $\begin{array}{l}\text { Presence of } \\
\text { significant } \\
\text { commercial species; } \\
\text { impact to } \\
\text { flora/fauna; loss of } \\
\text { commonly- } \\
\text { occurring species; } \\
\text { replacement of } \\
\text { commonly- } \\
\text { occurring species } \\
\text { with aquacultured } \\
\text { species; threats to }\end{array}$ & $\begin{array}{l}\text { Sites are in water depths greater } \\
\text { than } 4.5 \mathrm{ft} \text {. in order to avoid seagrass } \\
\text { beds; } 125 \mathrm{~m} \text { from all other wild } \\
\text { shellfish beds and commercial } \\
\text { shellfish growing operations; must be } \\
\text { at least } 1 \mathrm{~km} \text { from existing or } \\
\text { approved proposals for ecological } \\
\text { reserves < } 1000 \text { ha; must be an } \\
\text { appropriate distance from areas of } \\
\text { "sensitive fish habitat", as } \\
\text { determined by DFO and the } \\
\text { province; must be an appropriate }\end{array}$ & $\begin{array}{l}\text { DEP will monitor dominant species. If conditions } \\
\text { change, regulatory action may be triggered }\end{array}$ \\
\hline
\end{tabular}

- 9 - DRAFT 


\begin{tabular}{|c|c|c|c|c|c|}
\hline & & endangered species & & $\begin{array}{l}\text { distance from the areas used } \\
\text { extensively by marine mammals, as } \\
\text { determined by DFO and the province }\end{array}$ & \\
\hline \multirow{3}{*}{ 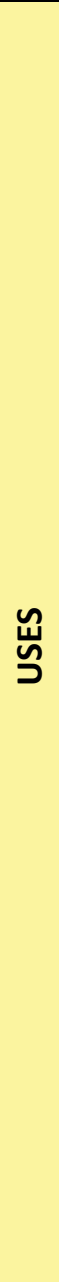 } & $\begin{array}{l}\text { Commercial } \\
\text { Fisheries }\end{array}$ & $\begin{array}{l}\text { Presence of } \\
\text { significant } \\
\text { commercial species; } \\
\text { gear entanglement }\end{array}$ & $\begin{array}{l}\text { Impact might be } \\
\text { greatest during } \\
\text { certain fishing } \\
\text { seasons; During } \\
\text { storms, increased } \\
\text { potential of } \\
\text { damage to support } \\
\text { structures, resulting } \\
\text { in floating debris - - } \\
\text { depending on } \\
\text { location of site }\end{array}$ & $\begin{array}{l}\text { Site must be } 300 \mathrm{~m} \text { from inter-tidal } \\
\text { shellfish beds that are exposed to } \\
\text { water flow from a salmon farm and } \\
\text { which have regular or traditional use } \\
\text { by First Nations, recreational, or } \\
\text { commercial fisheries; must be at } \\
\text { least } 125 \mathrm{~m} \text { from all other wild } \\
\text { shellfish beds and commercial } \\
\text { shellfish growing operations; not in } \\
\text { areas that would pre-empt important } \\
\text { Aboriginal, commercial or } \\
\text { recreational fisheries as determined } \\
\text { by the province in consultation with } \\
\text { First Nations and DFO }\end{array}$ & $\begin{array}{l}\text { License allows for prohibition on hand scalloping } \\
\text { under pens, but lobstering in the open areas of } \\
\text { the site outside the pen and mooring area will be } \\
\text { allowed; commercial and recreational fishing is } \\
\text { allowed over on-bottom shellfish leases if it does } \\
\text { not infringe on or interfere with the aquaculture } \\
\text { activity }\end{array}$ \\
\hline & Aquaculture & $\begin{array}{l}\text { Proximity to other } \\
\text { aquaculture } \\
\text { operations; } \\
\text { intensity and } \\
\text { frequency of use at } \\
\text { other sites }\end{array}$ & & $\begin{array}{l}\text { Project must be } 125 \mathrm{~m} \text { from all other } \\
\text { wild shellfish beds and commercial } \\
\text { shellfish growing operations; spacing } \\
\text { between farm sites to be three } \\
\text { kilometers or in accordance with a } \\
\text { local area plan or Coastal Zone } \\
\text { Management Plan (may be reduced } \\
\text { to one kilometer in the case of farms } \\
\text { operated by the same company); } \\
\text { must be at least } 3 \text { km from any } \\
\text { existing finfish aquaculture site, or in } \\
\text { accordance with a local area plan or } \\
\text { Coastal Zone Management Plan }\end{array}$ & \\
\hline & Oil \& Gas & $\begin{array}{l}\text { Physical occupation } \\
\text { of space; may be } \\
\text { opportunity to co- }\end{array}$ & & & \\
\hline
\end{tabular}

- 10 - DRAFT 


\begin{tabular}{|c|c|c|c|c|c|}
\hline & & \multicolumn{2}{|l|}{ locate } & & \\
\hline & $\begin{array}{l}\text { Sand \& Gravel } \\
\text { Mining }\end{array}$ & $\begin{array}{l}\text { Physical occupation } \\
\text { of space }\end{array}$ & & & \\
\hline & $\begin{array}{l}\text { Pipelines \& } \\
\text { Cables }\end{array}$ & $\begin{array}{l}\text { Physical occupation } \\
\text { of space; may be } \\
\text { opportunity to co- } \\
\text { locate }\end{array}$ & & & \\
\hline & Defense & & & & \\
\hline & Shipping & $\begin{array}{l}\text { Physical occupation } \\
\text { of space; collision } \\
\text { risks }\end{array}$ & $\begin{array}{l}\text { During storms, } \\
\text { increased potential } \\
\text { of damage to } \\
\text { support structures, } \\
\text { resulting in floating } \\
\text { debris - -depending } \\
\text { on location of site }\end{array}$ & $\begin{array}{l}\text { Minimum setback of } 100 \mathrm{ft} \text { from } \\
\text { marked navigation channels - } \\
\text { individual leases often have greater } \\
\text { setback distance from navigation } \\
\text { channels; must be at least } 30 \mathrm{~m} \text { from } \\
\text { the edge of the approach channel to } \\
\text { a small craft harbor, federal wharf or } \\
\text { dock }\end{array}$ & $\begin{array}{l}\text { Some vessel traffic is allowed over lease sites } \\
\text { located in water depths greater than } 5 \text { feet; } \\
\text { some individual leases will not be approved if } \\
\text { they "unreasonably" restrict access or obstruct } \\
\text { access to upland properties, channels, creeks, } \\
\text { marinas, and docks }\end{array}$ \\
\hline \multirow{4}{*}{ 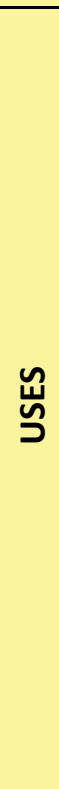 } & Anchorages & $\begin{array}{l}\text { Physical occupation } \\
\text { of space; collision } \\
\text { risks }\end{array}$ & $\begin{array}{l}\text { During storms, } \\
\text { increased potential } \\
\text { of damage to } \\
\text { support structures, } \\
\text { resulting in floating } \\
\text { debris - -depending } \\
\text { on location of site }\end{array}$ & & $\begin{array}{l}\text { Some vessel traffic is allowed over lease sites } \\
\text { located in water depths greater than } 5 \text { feet }\end{array}$ \\
\hline & Ferry Routes & $\begin{array}{l}\text { Physical occupation } \\
\text { of space; collision } \\
\text { risks }\end{array}$ & $\begin{array}{l}\text { During storms, } \\
\text { increased potential } \\
\text { of damage to } \\
\text { support structures, } \\
\text { resulting in floating } \\
\text { debris - -depending } \\
\text { on location of site }\end{array}$ & $\begin{array}{l}\text { Some individual leases will not be } \\
\text { approved if they "unreasonably" } \\
\text { restrict access or obstruct access to } \\
\text { upland properties, channels, creeks, } \\
\text { marinas, and docks; must be at least } \\
30 \mathrm{~m} \text { from the edge of the approach } \\
\text { channel to a small craft harbor, } \\
\text { federal wharf or dock }\end{array}$ & $\begin{array}{l}\text { Some vessel traffic is allowed over lease sites } \\
\text { located in water depths greater than } 5 \text { feet }\end{array}$ \\
\hline & $\begin{array}{l}\text { Onshore } \\
\text { Transportation }\end{array}$ & & & & \\
\hline & Civil Aviation & & & & \\
\hline
\end{tabular}




\begin{tabular}{|c|c|c|c|c|}
\hline \multirow{3}{*}{ 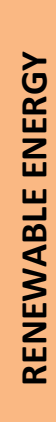 } & Wind & $\begin{array}{l}\text { May be opportunity } \\
\text { to co-locate }\end{array}$ & & \\
\hline & Tidal & $\begin{array}{l}\text { May be opportunity } \\
\text { to co-locate }\end{array}$ & & \\
\hline & Wave & $\begin{array}{l}\text { May be opportunity } \\
\text { to co-locate }\end{array}$ & & \\
\hline \multirow{3}{*}{ 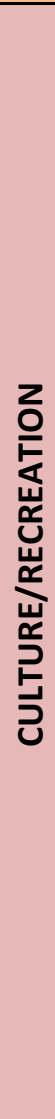 } & $\begin{array}{l}\text { Sites of } \\
\text { Archeological } \\
\text { Significance }\end{array}$ & $\begin{array}{l}\text { Damage to } \\
\text { resource }\end{array}$ & & \\
\hline & $\begin{array}{l}\text { Traditional } \\
\text { Rights }\end{array}$ & $\begin{array}{l}\text { Consistency with } \\
\text { First Nation } \\
\text { priorities }\end{array}$ & $\begin{array}{l}\text { Salmon opportunity areas not } \\
\text { typically allowed within } 1 \mathrm{~km} \text { of a } \\
\text { First Nations reserve; site at least } 300 \\
\mathrm{~m} \text { from inter-tidal shellfish beds that } \\
\text { are exposed to water flow from a } \\
\text { salmon farm and which have regular } \\
\text { or traditional use from First Nations, } \\
\text { recreational, or commercial fisheries; } \\
\text { site not in areas that would pre-empt } \\
\text { important Aboriginal, commercial or } \\
\text { recreational fisheries as determined } \\
\text { by the province in consultation with } \\
\text { First Nations and DFO; site not in } \\
\text { areas of cultural or heritage } \\
\text { significance as determined in the } \\
\text { Heritage Conservation Act }\end{array}$ & $\begin{array}{l}\text { Lessee and agents cannot use nearby island } \\
\text { except for the purpose of removing trash and } \\
\text { equipment from the island }\end{array}$ \\
\hline & Views & $\begin{array}{l}\text { Bottom cultures } \\
\text { have little/no visual } \\
\text { impact }\end{array}$ & $\begin{array}{l}\text { No salmon farms within the line of } \\
\text { sight up to } 1 \mathrm{~km} \text { in all directions from } \\
\text { existing federal, provincial or } \\
\text { regional parks, and Marine Protected } \\
\text { Areas; not in areas of cultural or } \\
\text { heritage significance as determined } \\
\text { in the Heritage Conservation Act }\end{array}$ & \\
\hline
\end{tabular}




\begin{tabular}{|c|c|c|c|c|c|}
\hline 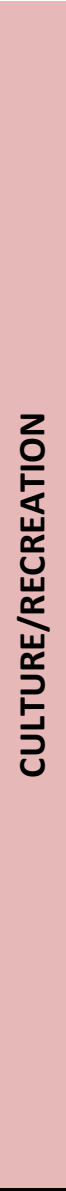 & Recreation & $\begin{array}{l}\text { Physical occupation } \\
\text { of space; collision } \\
\text { risks }\end{array}$ & $\begin{array}{l}\text { May have greater } \\
\text { impact during } \\
\text { fishing, swimming, } \\
\text { and boating } \\
\text { seasons; During } \\
\text { storms, increased } \\
\text { potential of } \\
\text { damage to support } \\
\text { structures, resulting } \\
\text { in floating debris - - } \\
\text { depending on } \\
\text { location of site }\end{array}$ & $\begin{array}{l}\text { Should not interfere with public } \\
\text { use/enjoyment within } 1,000 \mathrm{ft} \text {. of a } \\
\text { beach, park, docking facility or } \\
\text { certain conserved land owned by the } \\
\text { federal, state, or municipal } \\
\text { government; not allowed within } \\
1,000 \text { feet from nearby island to } \\
\text { ensure riparian access; } 300 \mathrm{~m} \text { from } \\
\text { inter-tidal shellfish beds that are } \\
\text { exposed to water flow from a salmon } \\
\text { farm and which have regular or } \\
\text { traditional use from First Nations, } \\
\text { recreational, or commercial fisheries; } \\
\text { no salmon farms within the line of } \\
\text { sight up to } 1 \text { km in all directions from } \\
\text { existing federal, provincial or } \\
\text { regional parks, and Marine Protected } \\
\text { Areas; must be at least } 30 \text { m from } \\
\text { the edge of the approach channel to } \\
\text { a small craft harbor, federal wharf or } \\
\text { dock; site not in areas that would } \\
\text { pre-empt important Aboriginal, } \\
\text { commercial or recreational fisheries } \\
\text { as determined by the province in } \\
\text { consultation with First Nations and } \\
\text { DFO; sites generally located } 1500- \\
2000 \text { feet offshore to minimize } \\
\text { conflict with upland landowners }\end{array}$ & $\begin{array}{l}\text { Proper navigation aids; prohibition on hand } \\
\text { scalloping under pens, but lobstering in the open } \\
\text { areas of the site outside the pen and mooring } \\
\text { area will be allowed; some vessel traffic is } \\
\text { allowed over lease sites located in water depths } \\
\text { greater than } 5 \text { feet; some individual leases will } \\
\text { not be approved if they "unreasonably" restrict } \\
\text { access or obstruct access to upland properties, } \\
\text { channels, creeks, marinas, and docks; } \\
\text { commercial and recreational fishing is allowed } \\
\text { over on-bottom shellfish leases if it does not } \\
\text { infringe on or interfere with the aquaculture } \\
\text { activity }\end{array}$ \\
\hline \multirow{3}{*}{ 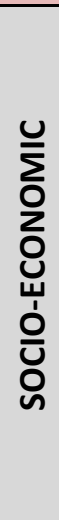 } & Jobs & & $\begin{array}{l}\text { Construction and } \\
\text { maintenance, } \\
\text { harvesting }\end{array}$ & & \\
\hline & $\begin{array}{l}\text { Onshore } \\
\text { Spending }\end{array}$ & & $\begin{array}{l}\text { Seed purchase, } \\
\text { employment, } \\
\text { construction, } \\
\text { licensing }\end{array}$ & & \\
\hline & Tourism & $\begin{array}{l}\text { Biosecurity; } \\
\text { sanitation }\end{array}$ & & $\begin{array}{l}\text { Site not in areas of cultural or } \\
\text { heritage significance as determined } \\
\text { in the Heritage Conservation Act; Ban } \\
\text { on aquaculture in areas of } \\
\text { importance to tourism }\end{array}$ & \\
\hline
\end{tabular}




\section{SUBMARINE CABLE SITING CONSIDERATIONS}

UMass Boston Planning Team, May 2009. This table presents information from a number of international projects. This table should only be used as an initial guide. Additional research would be necessary to identify actual spatial and temporal considerations, standards, conditions, compensations, and mitigation measures for a specific project. This document does not represent positions or conclusions of the preparers, MOP, or EOEEA.

In addition to the information contained in this table, there are some fundamental conditions to consider when siting submarine cables. These include:

- Appropriate technology for the depth and capacity of the cables

- Consistency with applicable planning goals and objectives

\begin{tabular}{|c|c|c|c|c|c|}
\hline & & $\begin{array}{l}\text { POTENTIAL SPATIAL } \\
\text { CONSIDERATIONS } \\
\text { (May be limited to the } \\
\text { duration of the } \\
\text { project) }\end{array}$ & $\begin{array}{l}\text { POTENTIAL TEMPORAL } \\
\text { CONSIDERATIONS } \\
\text { (May be limited to the } \\
\text { duration of the project) }\end{array}$ & $\begin{array}{l}\text { EXAMPLES OF } \\
\text { SITING } \\
\text { STANDARDS }\end{array}$ & $\begin{array}{c}\text { EXAMPLES OF } \\
\text { COMPENSATION/MITIGATION/CONDITIONS }\end{array}$ \\
\hline \multirow[b]{2}{*}{ 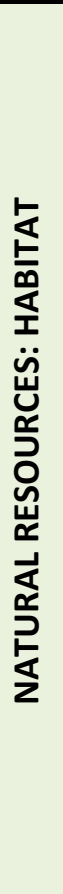 } & Habitat: Air & & $\begin{array}{l}\text { Air pollution during the } \\
\text { construction phase; light and } \\
\text { noise pollution from vessels } \\
\text { during construction }\end{array}$ & & $\begin{array}{l}\text { Use biodiesel, or other fuel which would result in lowest } \\
\text { emissions; minimize diesel engine fuel use; use shore-side } \\
\text { power when docked, rather than running engines; aim } \\
\text { work lights on the cable-laying ship and support vessels } \\
\text { to illuminate work areas in such a way as to minimize } \\
\text { spilling light into adjacent areas of water; construction } \\
\text { contractors should operate only well-maintained engines }\end{array}$ \\
\hline & $\begin{array}{l}\text { Habitat: } \\
\text { Surface }\end{array}$ & & $\begin{array}{l}\text { Vessel strikes during } \\
\text { installation; increased noise } \\
\text { during installation; water } \\
\text { pollution from vessel } \\
\text { discharges, etc. during } \\
\text { installation and repairs - both } \\
\text { on land (runoff) and } \\
\text { submarine; light pollution } \\
\text { from vessels during } \\
\text { construction; timing and } \\
\text { location of installation will } \\
\text { impact pinniped haul-out } \\
\text { areas }\end{array}$ & & $\begin{array}{l}\text { Vessel operators should update their fuel spill } \\
\text { contingency plans (based on NOAA's Environmental } \\
\text { Sensitivity Index) and continue to use emergency } \\
\text { response services for pollution incidents; use oil- } \\
\text { absorbent materials, maintained on the construction } \\
\text { vessels, in the event of a petroleum product spill on the } \\
\text { deck and/or if any sheen is observed in the water; } \\
\text { maintain vessels and equipment to minimize pollution; if } \\
\text { the cable is severed, whether due to a catastrophic } \\
\text { natural event (earthquake) or human caused event } \\
\text { (anchor), sensors in the system will stop the flow of } \\
\text { electrical current in the cable; aim work lights on the } \\
\text { cable-laying ship and support vessels to illuminate work } \\
\text { areas in such a way as to minimize spilling light into }\end{array}$ \\
\hline
\end{tabular}




\begin{tabular}{|c|c|c|c|c|}
\hline & & & & adjacent areas of water \\
\hline $\begin{array}{l}\text { Habitat: Water } \\
\text { Column }\end{array}$ & $\begin{array}{l}\text { Heat dispersal from } \\
\text { cable into sediment } \\
\text { and water (even if } \\
\text { cable is insulated) }\end{array}$ & $\begin{array}{l}\text { Disturbance during } \\
\text { installation stemming from } \\
\text { vessel noise and sediment } \\
\text { disruption from trenching, } \\
\text { digging and prop-wash; water } \\
\text { pollution from vessel } \\
\text { discharges, etc. during } \\
\text { installation and repairs - both } \\
\text { on land (runoff) and } \\
\text { submarine; stir up } \\
\text { contaminated sediment } \\
\text { during construction and } \\
\text { repair activities; light } \\
\text { pollution from vessels during } \\
\text { construction; on-shore } \\
\text { activities related to bringing } \\
\text { the cable on-shore may } \\
\text { impact water quality }\end{array}$ & $\begin{array}{l}\text { Construction } \\
\text { should avoid } \\
\text { known areas of } \\
\text { sediment } \\
\text { contamination }\end{array}$ & $\begin{array}{l}\text { Implement a hazardous materials management plan; } \\
\text { implement mitigation measures to minimize increased } \\
\text { sedimentation and pollution (including a hazardous } \\
\text { materials management plan and a plan for containing any } \\
\text { spills); comply with MARPOL regulations; sediment } \\
\text { sampling should be conducted in pre-determined sites } \\
\text { prior to construction; vessel operators should update } \\
\text { their fuel spill contingency plans (based on NOAA's } \\
\text { Environmental Sensitivity Index) and continue to use } \\
\text { emergency response services for pollution incidents; use } \\
\text { oil-adsorbent materials, maintained on the construction } \\
\text { vessels, in the event of a petroleum product spill on the } \\
\text { deck and/or if any sheen is observed in the water; } \\
\text { implement BMPs to reduce impact of drilling including } \\
\text { the release of drilling mud and the fracturing of near- } \\
\text { surface formations; maintain vessels and equipment to } \\
\text { minimize pollution; if the cable is severed, whether due } \\
\text { to a catastrophic natural event (earthquake) or human } \\
\text { caused event (anchor), sensors in the system will stop the } \\
\text { flow of electrical current in the cable; aim work lights on } \\
\text { the cable-laying ship and support vessels to illuminate } \\
\text { work areas in such a way as to minimize spilling light into } \\
\text { adjacent areas of water }\end{array}$ \\
\hline
\end{tabular}




\begin{tabular}{|c|c|c|c|c|c|}
\hline 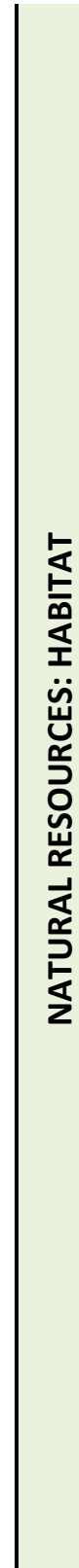 & $\begin{array}{l}\text { Habitat: } \\
\text { Benthic }\end{array}$ & $\begin{array}{l}\text { Heat dispersal from } \\
\text { cable into sediment } \\
\text { (even if cable is } \\
\text { insulated) }\end{array}$ & $\begin{array}{l}\text { Increased turbidity and } \\
\text { temporary loss of habitat } \\
\text { during installation (from } \\
\text { trenching, digging, and boat's } \\
\text { prop-wash); disruption of } \\
\text { longshore sediment } \\
\text { transport; installation and } \\
\text { repair activities - both on } \\
\text { land (runoff) and submarine - } \\
\text { can stir up contaminated } \\
\text { sediment; (temporary) } \\
\text { displacement of marine } \\
\text { vegetation from trenching } \\
\text { and sediment burial }\end{array}$ & $\begin{array}{l}\text { Avoid a cable } \\
\text { route that } \\
\text { negatively } \\
\text { impacts eel } \\
\text { grass beds }\end{array}$ & $\begin{array}{l}\text { Implement a hazardous materials management plan; } \\
\text { implement mitigation measures to minimize increased } \\
\text { sedimentation and pollution; clearing will be limited to } \\
\text { the minimum needed for safe implementation; areas of } \\
\text { habitat that are temporarily disturbed during cable } \\
\text { installation will be restored upon the completion of the } \\
\text { installation phase; trenches will be back filled and } \\
\text { vegetation recolonization will be encouraged through } \\
\text { replacing sediment to original depths; monthly } \\
\text { monitoring of restored benthic areas will be required for } \\
5 \text { months (with a focus on sediment transport and } \\
\text { erosion), with additional restoration and monitoring } \\
\text { conducted as needed; anchors will not be dragged on the } \\
\text { seafloor, and they will be retrieved vertically so as to } \\
\text { minimize disruption of benthic habitat; construction } \\
\text { should avoid known areas of sediment contamination and } \\
\text { sediment sampling should be conducted in pre- } \\
\text { determined sites prior to construction; vessel operators } \\
\text { should update their fuel spill contingency plans (based on } \\
\text { NOAA's Environmental Sensitivity Index) and continue to } \\
\text { use emergency response services for pollution incidents; } \\
\text { use jetting technology that minimizes sediment } \\
\text { disruption; if the cable is severed, whether due to a } \\
\text { catastrophic natural event (earthquake) or human caused } \\
\text { event (anchor), sensors in the system will stop the flow of } \\
\text { electrical current in the cable; use BMPs to reduce } \\
\text { turbidity and impact to sediment; the maximum speed of } \\
\text { the cable laying will not exceed } 6 \text { knots per hour so that } \\
\text { the amount of seabed sediment disturbed and dispersed } \\
\text { during the cable laying process can be kept to a } \\
\text { minimum; assess impacts to nearshore habitat at the } \\
\text { HDD hole end point and at trenching to a depth of } 70 \text { feet } \\
\text { ( } 21 \text { m) within two weeks after cable installation is } \\
\text { completed, and again after } 1 \text { year, during the growing } \\
\text { season. If the marine vegetation has not recovered to } \\
80 \% \text { of the density of adjacent areas within } 3 \text { years of } \\
\text { monitoring, develop a mitigation plan in consultation } \\
\text { with WDFW }\end{array}$ \\
\hline
\end{tabular}




\begin{tabular}{|c|c|c|c|c|}
\hline 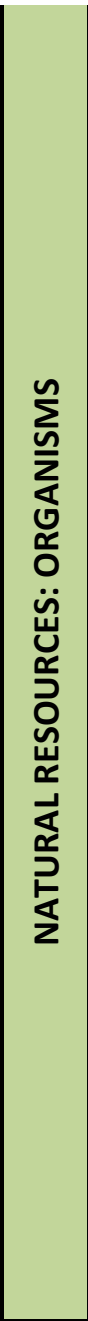 & Organisms: Air & & $\begin{array}{l}\text { Temporary impact of } \\
\text { installation (on migrating } \\
\text { birds); impact on electro- } \\
\text { sensitive organisms; bird } \\
\text { behavior disturbed due to } \\
\text { noise and light from vessels }\end{array}$ & $\begin{array}{l}\text { Cables have to be insulated (non-oil based) in order to } \\
\text { minimize their electromagnetic fields; have a trained } \\
\text { marine mammal observer on board the cable-laying } \\
\text { vessel to record any observations of marine mammals, } \\
\text { especially ESA-listed species; during nighttime operations, } \\
\text { observer would use low-light binoculars for observations. } \\
\text { During cable laying operations, observations for a } \\
\text { minimum of } 10 \text { min. would be made at least } 4 \\
\text { times/hour. If any listed species are observed, the } \\
\text { following procedures would apply: (1) If an } \\
\text { individual/group of animals is observed at 1,000 yds from } \\
\text { the cable-laying vessel, then behavior would be recorded } \\
\text { and vessel operators would be notified. No change to } \\
\text { cable-laying operations would be required. (2) If an } \\
\text { individual/group of animals approaches the cable-laying } \\
\text { vessel within } 500 \text { yds, the behavior of the animals would } \\
\text { be recorded, the vessel operator would be notified, and } \\
\text { preparations to reduce the speed of cable laying } \\
\text { operations would begin. (3) If an individual/group of } \\
\text { animals approaches the cable-laying vessel within } 400 \\
\text { yds, the behavior of the animals would be recorded, the } \\
\text { vessel operator would be notified, and cable-laying } \\
\text { operations would be reduced to half speed. The operator } \\
\text { would prepare to stop cable-laying operation if } \\
\text { necessary. (4) If an individual/group of animals } \\
\text { approaches the cable-laying vessel within } 100 \text { yds, the } \\
\text { behavior of the animals would be recorded, the vessel } \\
\text { operator would be notified, and cable-laying operations } \\
\text { would cease until the individual/group of animals had } \\
\text { moved beyond } 100 \text { yds of the vessel, then reduced-speed } \\
\text { operations may be resumed }\end{array}$ \\
\hline 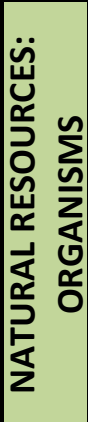 & $\begin{array}{l}\text { Organisms: } \\
\text { Surface }\end{array}$ & $\begin{array}{l}\text { Introduction of } \\
\text { invasive species from } \\
\text { construction vessels }\end{array}$ & $\begin{array}{l}\text { Impact on electro-sensitive } \\
\text { organisms; vessel-based } \\
\text { disturbances during } \\
\text { installation, including vessel } \\
\text { strikes; disruption of } \\
\text { breeding, migration and } \\
\text { feeding during installation } \\
\text { due to increased vessel noise; } \\
\text { ingestion of pollutants stirred } \\
\text { up during installation }\end{array}$ & $\begin{array}{l}\text { Cables have to be insulated (non-oil based) in order to } \\
\text { minimize their electromagnetic fields; adhere to IMO } \\
\text { regulations; monitoring required for marine mammals } \\
\text { and turtles during installation and other marine activities; } \\
\text { vessel crews must report the sighting of any injured or } \\
\text { dead sea turtles or marine mammals (even if death or } \\
\text { injury is not related to project); deploy any item or } \\
\text { material that has the potential for entangling marine } \\
\text { mammals only as long as necessary to perform its task, } \\
\text { and then immediately remove it from the project site; in }\end{array}$ \\
\hline
\end{tabular}

- 17 - DRAFT 


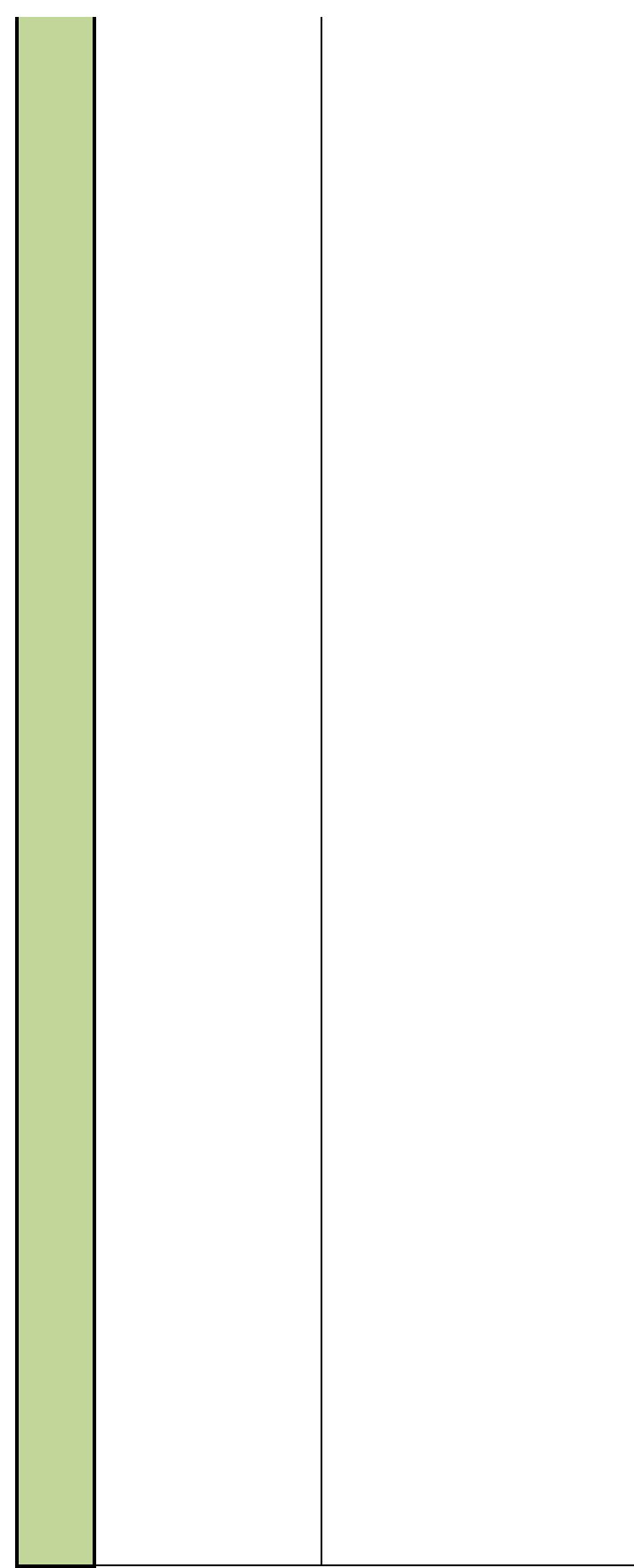

(biomagnification); noise, wake, and light from vessels may disturb bird and fish behavior the unlikely event that a marine mammal becomes entangled, immediately notify the

stranding coordinator at NOAA Fisheries so that a rescue effort can be initiated; have a trained marine mammal observer on board the cable-laying vessel to record any observations of marine mammals, especially ESA-listed species; vessel operators will maintain a distance of 100 $\mathrm{m}$ or greater and will travel at 10 knots or less when safety permits until animals are more than $500 \mathrm{~m}$ away. Abrupt changes in direction will be avoided; implement appropriate mitigation measures as required by USFWS, NOAA, or WDFW through consultations, including potential work windows (for example, no in-water work from March 2 through July 15 to protect migrating juvenile salmonids); during nighttime operations, the observer would use low-light binoculars for observations. During nighttime operations, observer would use lowlight binoculars for observations. During cable laying operations, observations for a minimum of $10 \mathrm{~min}$. would be made at least 4 times/hour. If any listed species are observed, the following procedures would apply: (1) If an individual/group of animals is observed at 1,000 yds from the cable-laying vessel, then behavior would be recorded and vessel operators would be notified. No change to cable-laying operations would be required. (2) If an individual/group of animals approaches the cable-laying vessel within $500 \mathrm{yds}$, the behavior of the animals would be recorded, the vessel operator would be notified, and preparations to reduce the speed of cable laying operations would begin. (3) If an individual/group of animals approaches the cable-laying vessel within 400 $y d s$, the behavior of the animals would be recorded, the vessel operator would be notified, and cable-laying operations would be reduced to half speed. The operator would prepare to stop cable-laying operation if necessary. (4) If an individual/group of animals approaches the cable-laying vessel within $100 \mathrm{yds}$, the behavior of the animals would be recorded, the vessel operator would be notified, and cable-laying operations would cease until the individual/group of animals had moved beyond $100 \mathrm{yds}$ of the vessel, then reduced-speed 


\begin{tabular}{|c|c|c|c|c|}
\hline & & & & operations may be resumed \\
\hline 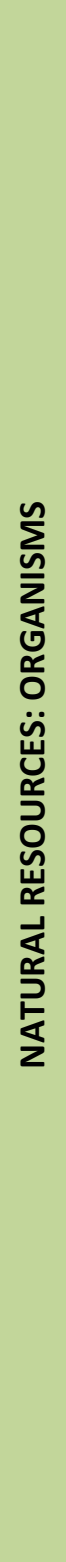 & $\begin{array}{l}\text { Organisms: } \\
\text { Water Column }\end{array}$ & $\begin{array}{l}\text { Introduction of } \\
\text { invasive species from } \\
\text { construction vessels }\end{array}$ & $\begin{array}{l}\text { Temporary impact of } \\
\text { installation (on spawning fish, } \\
\text { from entanglement with } \\
\text { equipment or impact from } \\
\text { prop wash); impact on } \\
\text { electro-sensitive organisms; } \\
\text { new habitat on/around non- } \\
\text { submerged cables; disrupted } \\
\text { breeding, migration and } \\
\text { feeding during installation } \\
\text { from vessel noise and light } \\
\text { pollution; smothering from } \\
\text { sediment disruption during } \\
\text { the cable-laying process; } \\
\text { increased nutrients available } \\
\text { to filter feeders during } \\
\text { construction activities; } \\
\text { ingestion of pollutants stirred } \\
\text { up during installation } \\
\text { (biomagnification) }\end{array}$ & $\begin{array}{l}\text { Cables have to be insulated (non-oil based) in order to } \\
\text { minimize their electromagnetic fields; adhere to IMO } \\
\text { regulations; monitor for marine mammals and turtles } \\
\text { during installation and other marine activities; implement } \\
\text { mitigation measures to minimize increased } \\
\text { sedimentation and water pollution; vessel crews must } \\
\text { report the sighting of any injured or dead sea turtles or } \\
\text { marine mammals (even if death or injury is not related to } \\
\text { project); deploy any item or material that has the } \\
\text { potential for entangling marine mammals only as long as } \\
\text { necessary to perform its task, and then immediately } \\
\text { remove it from the project site; in the unlikely event that } \\
\text { a marine mammal becomes entangled, immediately } \\
\text { notify the stranding coordinator at NOAA Fisheries so } \\
\text { that a rescue effort can be initiated; have a trained } \\
\text { marine mammal observer on board the cable-laying } \\
\text { vessel to record any observations of marine mammals, } \\
\text { especially ESA-listed species; Vessel operators will } \\
\text { maintain a distance of } 100 \text { m or greater and will travel at } \\
10 \text { knots or less when safety permits until animals are } \\
\text { more than } 500 \text { m away. Abrupt changes in direction will } \\
\text { be avoided; implement appropriate mitigation measures } \\
\text { as required by USFWS, NOAA, and WDFW through } \\
\text { consultations, including potential work windows (for } \\
\text { example, no in-water work from March } 2 \text { through July } 15 \\
\text { to protect migrating juvenile salmonids; during nighttime } \\
\text { operations, the observer would use low-light binoculars } \\
\text { for observations. During cable laying operations, } \\
\text { observations for a minimum of } 10 \text { minutes would be } \\
\text { made at least four times each hour. If any listed species } \\
\text { are observed, the following procedures would be } \\
\text { followed: (1) If an individual or group of animals is } \\
\text { observed at } 1,000 \text { yards ( } 915 \text { m) from the cable-laying } \\
\text { vessel, then behavior would be recorded and vessel } \\
\text { operators would be notified. No change to cable-laying } \\
\text { operations would be required. (2) If an individual or } \\
\text { group of animals approaches the cable-laying vessel }\end{array}$ \\
\hline
\end{tabular}




\begin{tabular}{|c|c|c|c|}
\hline & & & $\begin{array}{l}\text { within } 500 \text { yards ( } 457 \mathrm{~m}) \text {, the behavior of the animals } \\
\text { would continue to be recorded, and the vessel operator } \\
\text { would be notified and preparations to reduce the speed } \\
\text { of cable laying operations would begin. ( } 3 \text { ) If an individual } \\
\text { or group of animals approaches the cable-laying vessel } \\
\text { within } 400 \text { yards ( } 366 \mathrm{~m}) \text {, the behavior of the animals } \\
\text { would continue to be recorded, the vessel operator } \\
\text { would be notified, and cable-laying operations would be } \\
\text { reduced to one-half speed. The operator would prepare } \\
\text { to stop cable-laying operation if necessary. ( } 4 \text { ) If an } \\
\text { individual or group of animals approaches the cable- } \\
\text { laying vessel within } 100 \text { yards ( } 91 \mathrm{~m}) \text {, the behavior of the } \\
\text { animals would continue to be recorded, the vessel } \\
\text { operator would be notified, and cable-laying operations } \\
\text { would cease until the individual or group of animals had } \\
\text { moved beyond } 100 \text { yards }(91 \mathrm{~m} \text { ) of the vessel, then } \\
\text { reduced-speed operations may be resumed }\end{array}$ \\
\hline $\begin{array}{l}\text { Organisms: } \\
\text { Benthic }\end{array}$ & $\begin{array}{l}\text { Introduction of } \\
\text { invasive species from } \\
\text { construction vessels; } \\
\text { impact on electro- } \\
\text { sensitive organisms; } \\
\text { new habitat on/near } \\
\text { non-submerged cables }\end{array}$ & $\begin{array}{l}\text { Ecological recovery of the } \\
\text { disturbed seabed in the } \\
\text { vicinity of offshore wind } \\
\text { cables during construction } \\
\text { would be rapid; disrupted } \\
\text { breeding, migration and } \\
\text { feeding during installation } \\
\text { from construction vessel } \\
\text { noise; smothering/crushing } \\
\text { from sediment disruption } \\
\text { during the cable-laying } \\
\text { process; increased nutrients } \\
\text { available to filter feeders } \\
\text { because of installation } \\
\text { activities; ingestion of } \\
\text { pollutants stirred up during } \\
\text { installation } \\
\text { (biomagnification) }\end{array}$ & $\begin{array}{l}\text { Cables have to be insulated (non-oil based) in order to } \\
\text { minimize their electromagnetic fields; adhere to IMO } \\
\text { regulations; implement mitigation measures to minimize } \\
\text { increased sedimentation and water pollution; } \\
\text { compensatory mitigation, if required, for the loss of } \\
\text { Geoduck clams would be negotiated with the } \\
\text { Department of Natural Resources (DNR) and the WDFW; } \\
\text { mitigate loss of geoducks based on agreements with the } \\
\text { DNR and WDFW; monitor beach within } 100 \text { feet of the } \\
\text { route for concentrations of crab and urchins, under the } \\
\text { supervision of a qualified biologist over a two-week } \\
\text { period prior to installation for any work occurring } \\
\text { between February and September. If survey identifies an } \\
\text { unexpectedly high concentration of these priority species } \\
\text { that would be directly impacted by the project, then } \\
\text { determine additional mitigation requirements in } \\
\text { consultation with WDFW; implement appropriate } \\
\text { mitigation measures as required by USFWS, NOAA, and } \\
\text { WDFW through consultations, including potential work } \\
\text { windows (for example, no in-water work from March } 2 \\
\text { through July } 15 \text { to protect migrating juvenile salmonids) }\end{array}$ \\
\hline
\end{tabular}




\begin{tabular}{|c|c|c|c|c|}
\hline 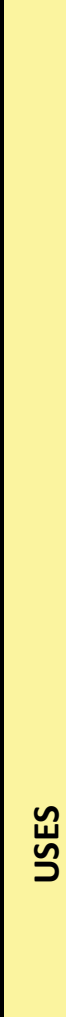 & $\begin{array}{l}\text { Commercial } \\
\text { Fisheries }\end{array}$ & Gear entanglement & $\begin{array}{l}\text { Animals may ingest } \\
\text { pollutants stirred up during } \\
\text { installation } \\
\text { (biomagnification); vessel } \\
\text { collisions (mostly limited to } \\
\text { times of installation and } \\
\text { repairs) }\end{array}$ & $\begin{array}{l}\text { Contractors must implement procedures to reduce risk of } \\
\text { vessel collision; vessels will increase watch when } \\
\text { navigating in areas that are known to be used by } \\
\text { fishermen and other vessels. If other vessels are observed } \\
\text { within the near vicinity, the Project vessel will stop } \\
\text { moving, make contact with the other vessel if possible, } \\
\text { and wait until it has been confirmed that the course of } \\
\text { both vessels will not result in collision or damage to } \\
\text { equipment; while a ship is laying cable its } \\
\text { maneuverability is restricted, as such it will display the } \\
\text { day signals and lights of a hampered vessel to avoid } \\
\text { collision with other vessels at sea; crews will watch for } \\
\text { navigational hazards; coordinate construction with USCG } \\
\text { who will issue a Local Notice to Mariners which identifies } \\
\text { a safety precaution area around the working boat; all } \\
\text { ships operating under a foreign registry must have a Pilot } \\
\text { escort them into the area; vessels laying cable must } \\
\text { identify themselves and follow all applicable navigation } \\
\text { rules; no trawling within } 200 \text { m around submarine cables; } \\
\text { fishing vessels must keep their implements or nets at a } \\
\text { distance of at least } 1 \text { nautical mile from a vessel engaged } \\
\text { in laying or repairing a cable or at least } 1 / 4 \text { of a nautical } \\
\text { mile from buoys intended to mark the position of a cable } \\
\text { when being laid or when out of order }\end{array}$ \\
\hline & Aquaculture & $\begin{array}{l}\text { Physical occupation of } \\
\text { space }\end{array}$ & & \\
\hline & Oil \& Gas & $\begin{array}{l}\text { Physical occupation of } \\
\text { space (related to both } \\
\text { structures and drilling) }\end{array}$ & & \\
\hline & $\begin{array}{l}\text { Sand \& Gravel } \\
\text { Mining }\end{array}$ & $\begin{array}{l}\text { Interference with } \\
\text { extraction activities }\end{array}$ & & $\begin{array}{l}\text { No sand or gravel mining for the life of offshore wind } \\
\text { turbine operations because of potential damage to } \\
\text { cables; sand extraction is not permitted in a zone with a } \\
\text { width of } 500 \text { meters around cables; no recovery of raw } \\
\text { materials within an area of } 200 \mathrm{~m} \text { around submarine } \\
\text { cables }\end{array}$ \\
\hline & Cables & $\begin{array}{l}\text { Interference with } \\
\text { other cables; } \\
\text { opportunity for co- } \\
\text { location }\end{array}$ & & \\
\hline
\end{tabular}




\begin{tabular}{|c|c|c|c|c|}
\hline Pipelines & $\begin{array}{l}\text { Opportunity for co- } \\
\text { location }\end{array}$ & & & \\
\hline \multicolumn{5}{|l|}{ Defense } \\
\hline Shipping & $\begin{array}{l}\text { Conflict with } \\
\text { development of new } \\
\text { ports }\end{array}$ & $\begin{array}{l}\text { Potential for vessel collisions } \\
\text { (mostly limited to times of } \\
\text { installation and repairs) }\end{array}$ & $\begin{array}{l}\text { Cable route } \\
\text { selected to } \\
\text { avoid major } \\
\text { shipping } \\
\text { channels }\end{array}$ & $\begin{array}{l}\text { Cable routes will be added to navigational charts; cables } \\
\text { must be "armored" and buried in areas where anchoring } \\
\text { or scouring might occur; contractors must implement } \\
\text { procedures to reduce risk of vessel collision; vessels will } \\
\text { increase watch when navigating in areas that are known } \\
\text { to be used by fishermen and other vessels. If other } \\
\text { vessels are observed within the near vicinity, the Project } \\
\text { vessel will stop moving, make contact with the other } \\
\text { vessel if possible, and wait until it has been confirmed } \\
\text { that the course of both vessels will not result in collision } \\
\text { or damage to equipment; while a ship is laying cable its } \\
\text { maneuverability is restricted, as such it will display the } \\
\text { day signals and lights of a hampered vessel to avoid } \\
\text { collision with other vessels at sea; crews will watch for } \\
\text { navigational hazards; coordinate construction with USCG } \\
\text { who will issue a Local Notice to Mariners which identifies } \\
\text { a safety precaution area around the working boat; all } \\
\text { ships operating under a foreign registry must have a Pilot } \\
\text { escort them into the area; vessels laying cable must } \\
\text { identify themselves and follow all applicable navigation } \\
\text { rules; if the cable were severed, the electricity would } \\
\text { instantaneously turn-off; vessels must maintain a } 1.15 \\
\text { mile separation from a vessel laying or repairing an } \\
\text { undersea cable }\end{array}$ \\
\hline Anchorages & $\begin{array}{l}\text { Anchors damaging } \\
\text { cables; cables } \\
\text { entangling anchors }\end{array}$ & & $\begin{array}{l}\text { Avoid siting } \\
\text { cables in } \\
\text { anchorages }\end{array}$ & $\begin{array}{l}\text { Cables must be "armored" and buried in areas where } \\
\text { anchoring or scouring might occur; bury the cable bundle } \\
\text { deep enough to provide protection, up to } 12 \text { feet ( } 3.6 \mathrm{~m} \text { ), } \\
\text { in areas of soft soils and potential ship anchorage; if the } \\
\text { cable is severed, whether due to a catastrophic natural } \\
\text { event (earthquake) or human caused event (anchor), } \\
\text { sensors in the system will stop the flow of electrical } \\
\text { current in the cable; no anchoring within an area of } 200 \\
\mathrm{~m} \text { around submarine cables }\end{array}$ \\
\hline
\end{tabular}




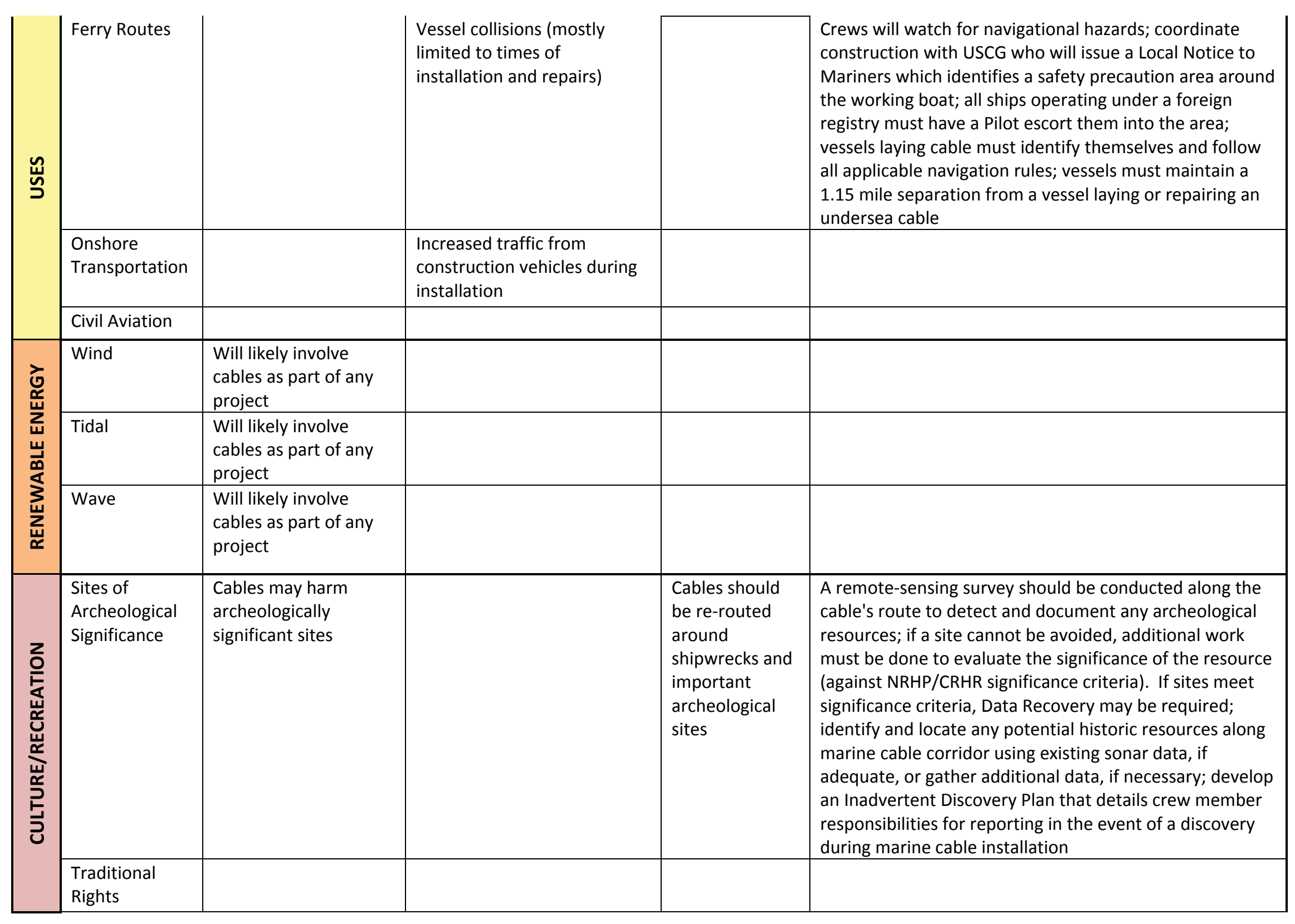




\begin{tabular}{|c|c|c|c|c|}
\hline & Views & & $\begin{array}{l}\text { Vessels visible from certain } \\
\text { locations during installation } \\
\text { and repairs; an attraction for } \\
\text { those who want to view the } \\
\text { boats and equipment used } \\
\text { during installation }\end{array}$ & \\
\hline & Recreation & $\begin{array}{l}\text { Non-submerged cables } \\
\text { can interfere with } \\
\text { boating; fishing gear } \\
\text { entanglement }\end{array}$ & $\begin{array}{l}\text { Animals can ingest pollutants } \\
\text { stirred up during installation } \\
\text { (biomagnification); vessel } \\
\text { collisions (mostly limited to } \\
\text { times of installation and } \\
\text { repairs) }\end{array}$ & $\begin{array}{l}\text { Cable routes will be added to navigational charts; cables } \\
\text { must be "armored" and buried in areas where anchoring } \\
\text { or scouring might occur; contractors must implement } \\
\text { procedures to reduce risk of vessel collision; vessels will } \\
\text { increase watch when navigating in areas that are known } \\
\text { to be used by fishermen and other vessels. If other } \\
\text { vessels are observed within the near vicinity, the Project } \\
\text { vessel will stop moving, make contact with the other } \\
\text { vessel if possible, and wait until it has been confirmed } \\
\text { that the course of both vessels will not result in collision } \\
\text { or damage to equipment; while a ship is laying cable its } \\
\text { maneuverability is restricted, as such it will display the } \\
\text { day signals and lights of a hampered vessel to avoid } \\
\text { collision with other vessels at sea; crews will watch for } \\
\text { navigational hazards; coordinate construction with USCG } \\
\text { who will issue a Local Notice to Mariners which identifies } \\
\text { a safety precaution area around the working boat; all } \\
\text { ships operating under a foreign registry must have a San } \\
\text { Francisco Bar Pilot escort them into the Bay; vessels } \\
\text { laying cable must identify themselves and follow all } \\
\text { applicable navigation rules; vessels must maintain a } 1.15 \\
\text { mile separation from a vessel laying or repairing an } \\
\text { undersea cable }\end{array}$ \\
\hline 을 & Jobs & & $\begin{array}{l}\text { Create new job opportunities } \\
\text { in the community; } \\
\text { temporarily displace fishing } \\
\text { operations }\end{array}$ & \\
\hline ns & $\begin{array}{l}\text { Onshore } \\
\text { Spending }\end{array}$ & & $\begin{array}{l}\text { New onshore spending } \\
\text { during construction }\end{array}$ & \\
\hline
\end{tabular}




\begin{tabular}{|c|c|c|}
\hline Tourism & $\begin{array}{l}\text { Loss of tourists who } \\
\text { would have come to } \\
\text { dive on any shipwrecks } \\
\text { discovered and } \\
\text { destroyed by } \\
\text { installation }\end{array}$ & $\begin{array}{l}\text { Identify and locate any potential historic resources along } \\
\text { marine cable corridor using existing sonar data, if } \\
\text { adequate, or gather additional data, if necessary }\end{array}$ \\
\hline
\end{tabular}




\section{OFFSHORE WIND ENERGY SITING CONSIDERATIONS}

UMass Boston Planning Team, May 2009. This table presents information from a number of international projects. This table should only be used as an initial guide. Additional research would be necessary to identify actual spatial and temporal considerations, standards, conditions, compensations, and mitigation measures for a specific project. This document does not represent positions or conclusions of the preparers, MOP, or EOEEA.

In addition to the information contained in this table, there are some fundamental conditions to consider when siting an offshore wind project. They include:

- Appropriate water depths, substrate, and wind speeds for the technology being used

- Adequate proximity to land-based electrical connections

- Consistent with applicable planning goals and objectives

\begin{tabular}{|c|c|c|c|c|c|}
\hline & & $\begin{array}{c}\text { POTENTIAL } \\
\text { SPATIAL } \\
\text { CONSIDERATIONS } \\
\text { (May be limited to } \\
\text { the duration of the } \\
\text { project) }\end{array}$ & $\begin{array}{c}\text { POTENTIAL } \\
\text { TEMPORAL } \\
\text { CONSIDERATIONS } \\
\text { (May be limited to } \\
\text { the duration of the } \\
\text { project) }\end{array}$ & $\begin{array}{l}\text { EXAMPLES OF SITING } \\
\text { STANDARDS }\end{array}$ & $\begin{array}{c}\text { EXAMPLES OF } \\
\text { COMPENSATION/MITIGATION/CONDITIONS }\end{array}$ \\
\hline 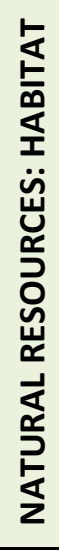 & Habitat: Air & $\begin{array}{l}\text { Physical occupation } \\
\text { of space (collision, } \\
\text { creation of barrier); } \\
\text { air turbidity; new } \\
\text { roosting habitat; } \\
\text { noise }\end{array}$ & $\begin{array}{l}\text { Temporary } \\
\text { localized air quality } \\
\text { impacts from } \\
\text { vessels during } \\
\text { construction; may } \\
\text { improve air quality } \\
\text { over the course of } \\
\text { time; spatial } \\
\text { impacts may be } \\
\text { more significant } \\
\text { during times of } \\
\text { migration, feeding, } \\
\text { and construction }\end{array}$ & $\begin{array}{l}\text { Wind farms not allowed } \\
\text { in any special areas of } \\
\text { conservation/protection }\end{array}$ & $\begin{array}{l}\text { Install lighting systems to minimize attraction while } \\
\text { meeting aviation standards; secure air quality offsets for } \\
\text { construction emission impacts; vessels must be } \\
\text { maintained to ensure efficient use of fuel; a waste } \\
\text { management plan must be in place prior to construction; } \\
\text { monitor noise; conduct a multi-year analysis of avian use } \\
\text { (before, during, and after construction), including } \\
\text { species-specific uses and population; adhere to specific } \\
\text { construction methods to minimize environmental impact; } \\
\text { time construction to avoid migrations and breeding; } \\
\text { avoid population-level impacts }\end{array}$ \\
\hline
\end{tabular}




\begin{tabular}{|c|c|c|c|c|}
\hline $\begin{array}{l}\text { Habitat: } \\
\text { Surface }\end{array}$ & $\begin{array}{l}\text { Physical occupation } \\
\text { of space from } \\
\text { turbines and } \\
\text { construction } \\
\text { equipment (collision, } \\
\text { creation of barrier); } \\
\text { vibrations; noise; } \\
\text { contamination from } \\
\text { anti-fouling paint, } \\
\text { vessels, and } \\
\text { equipment }\end{array}$ & $\begin{array}{l}\text { Spatial impacts may } \\
\text { be more significant } \\
\text { during times of } \\
\text { spawning, } \\
\text { migration, feeding, } \\
\text { and construction }\end{array}$ & $\begin{array}{l}\text { Wind farms not allowed } \\
\text { in any special areas of } \\
\text { conservation/protection }\end{array}$ & $\begin{array}{l}\text { All oil filled equipment is fully bundled to ensure no } \\
\text { spillage in the event of a leak or puncture in any vessels } \\
\text { or the offshore substation; a waste management plan } \\
\text { must be in place prior to construction; monitor the } \\
\text { impacts of vibrations; minimize risks through the } \\
\text { application of best management practices for } \\
\text { construction and operation; include seasonal restrictions } \\
\text { on construction as needed }\end{array}$ \\
\hline $\begin{array}{l}\text { Habitat: Water } \\
\text { Column }\end{array}$ & $\begin{array}{l}\text { Physical occupation } \\
\text { of space (creation of } \\
\text { barrier); vibrations; } \\
\text { contamination from } \\
\text { anti-fouling paint, } \\
\text { vessels, and } \\
\text { equipment; } \\
\text { electromagnetic } \\
\text { field; noise (during } \\
\text { construction and } \\
\text { operation); turbidity; } \\
\text { creation of artificial } \\
\text { reef; create new } \\
\text { habitat type; attract } \\
\text { feeding species }\end{array}$ & $\begin{array}{l}\text { Spatial impacts may } \\
\text { be more significant } \\
\text { during times of } \\
\text { spawning, } \\
\text { migration, feeding, } \\
\text { and construction }\end{array}$ & $\begin{array}{l}\text { Wind farms not allowed } \\
\text { in any special areas of } \\
\text { conservation/protection }\end{array}$ & $\begin{array}{l}\text { Insulate cables to reduce impact of magnetic field; a } \\
\text { waste management plan must be in place prior to } \\
\text { construction; all oil filled equipment is fully bundled to } \\
\text { ensure no spillage in the event of a leak or puncture in } \\
\text { any vessels or the offshore substation; power cables } \\
\text { would use an alternative non-oil based solid insulator; } \\
\text { TBT based anti-fouling paints would not be used on the } \\
\text { submerged surfaces of foundations -- instead, barnacles } \\
\text { and mussels attached to the foundation would be } \\
\text { removed by scraping if necessary; adhere to specific } \\
\text { construction methods (such as soft-start pile driving, } \\
\text { bubble curtains, or other noise-dampening procedures } \\
\text { during pile driving) to minimize environmental impact; } \\
\text { monitor sedimentary and hydrological processes, } \\
\text { electromagnetic fields, noise, vibrations, suspended } \\
\text { sediment concentrations, contaminants, and currents; } \\
\text { include seasonal restrictions on construction as needed; } \\
\text { to prevent corrosion, sacrificial aluminum based anodes } \\
\text { may be placed on foundations. These are designed to } \\
\text { slowly break down and would release aluminum } \\
\text { gradually into the water }\end{array}$ \\
\hline
\end{tabular}




\begin{tabular}{|c|c|c|c|c|c|}
\hline 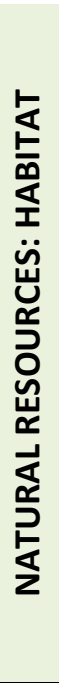 & $\begin{array}{l}\text { Habitat: } \\
\text { Benthic }\end{array}$ & $\begin{array}{l}\text { Physical occupation } \\
\text { of space (creation of } \\
\text { barrier); disruption } \\
\text { of sediment } \\
\text { transport; loss of } \\
\text { habitat from } \\
\text { scouring; vibrations; } \\
\text { turbidity; noise; } \\
\text { contamination from } \\
\text { anti-fouling paint } \\
\text { vessels, and } \\
\text { equipment; } \\
\text { electromagnetic } \\
\text { field; potential to } \\
\text { create new habitat } \\
\text { type }\end{array}$ & $\begin{array}{l}\text { Spatial impacts may } \\
\text { be more significant } \\
\text { during times of } \\
\text { spawning, } \\
\text { migration, feeding, } \\
\text { and construction }\end{array}$ & $\begin{array}{l}\text { Wind farms not allowed } \\
\text { in any special areas of } \\
\text { conservation/protection; } \\
\text { cables allowed in special } \\
\text { areas of } \\
\text { conservation/protection }\end{array}$ & $\begin{array}{l}\text { All oil filled equipment is fully bundled to ensure no } \\
\text { spillage in the event of a leak or puncture in any vessels } \\
\text { or the offshore substation; power cables use an } \\
\text { alternative non-oil based solid insulator; adhere to } \\
\text { specific construction methods to minimize environmental } \\
\text { impact; a waste management plan must be in place prior } \\
\text { to construction; armor and bury cables in those areas } \\
\text { where anchoring or scouring might occur; insulate cables } \\
\text { to reduce impact of magnetic field; monitor sedimentary } \\
\text { and hydrological processes, benthic ecology, } \\
\text { electromagnetic fields, noise, vibrations, suspended } \\
\text { sediment concentrations, and contaminants; include } \\
\text { seasonal restrictions as needed }\end{array}$ \\
\hline \multirow{2}{*}{ 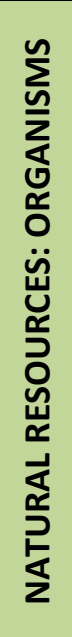 } & Organisms: Air & $\begin{array}{l}\text { Increased mortality } \\
\text { (collision); } \\
\text { displacement from } \\
\text { area; attracting } \\
\text { birds, bats, etc. with } \\
\text { the lights; new } \\
\text { roosting } \\
\text { opportunities; new } \\
\text { food sources }\end{array}$ & $\begin{array}{l}\text { Spatial impacts may } \\
\text { be more significant } \\
\text { during times of } \\
\text { migration, feeding, } \\
\text { and construction }\end{array}$ & $\begin{array}{l}\text { Wind farms not allowed } \\
\text { in any special areas of } \\
\text { conservation/protection }\end{array}$ & $\begin{array}{l}\text { Install lighting system to minimize attraction while } \\
\text { meeting aviation standards; consider cumulative impacts } \\
\text { on birds; adhere to specific construction methods to } \\
\text { minimize environmental impact; conduct a multi-year } \\
\text { analysis of avian use (before, during, and after } \\
\text { construction), including species-specific uses and } \\
\text { population; time construction to avoid migrations and } \\
\text { breeding; avoid population-level impacts }\end{array}$ \\
\hline & $\begin{array}{l}\text { Organisms: } \\
\text { Surface }\end{array}$ & $\begin{array}{l}\text { Displacement from } \\
\text { area; new feeding } \\
\text { opportunities; } \\
\text { change in species } \\
\text { composition }\end{array}$ & $\begin{array}{l}\text { Spatial impacts may } \\
\text { be more significant } \\
\text { during times of } \\
\text { spawning, } \\
\text { migration, feeding, } \\
\text { and construction }\end{array}$ & $\begin{array}{l}\text { Wind farms not allowed } \\
\text { in any special areas of } \\
\text { conservation/protection }\end{array}$ & $\begin{array}{l}\text { All oil filled equipment will be fully bundled to ensure no } \\
\text { spillage in the event of a leak or puncture in any vessels } \\
\text { or the offshore substation; adhere to specific } \\
\text { construction methods to minimize environmental impact, } \\
\text { including seasonal restrictions as necessary; a waste } \\
\text { management plan must be in place prior to construction }\end{array}$ \\
\hline
\end{tabular}




\begin{tabular}{|c|c|c|c|c|c|}
\hline & $\begin{array}{l}\text { Organisms: } \\
\text { Water Column }\end{array}$ & $\begin{array}{l}\text { Increased } \\
\text { biodiversity and } \\
\text { number of } \\
\text { organisms (because } \\
\text { of new reef habitat); } \\
\text { loss of organisms } \\
\text { during construction } \\
\text { or in the event of } \\
\text { contamination; } \\
\text { disruption of } \\
\text { behavior because of } \\
\text { electromagnetic } \\
\text { field, noise, and/or } \\
\text { vibrations }\end{array}$ & $\begin{array}{l}\text { Spatial impacts may } \\
\text { be more significant } \\
\text { during times of } \\
\text { spawning, } \\
\text { migration, feeding, } \\
\text { and construction }\end{array}$ & $\begin{array}{l}\text { Wind farms not allowed } \\
\text { in any special areas of } \\
\text { conservation/protection }\end{array}$ & $\begin{array}{l}\text { All oil filled equipment would be fully bundled to ensure } \\
\text { no spillage in the event of a leak or puncture in any } \\
\text { vessels or the offshore substation; Power cables would } \\
\text { use an alternative non-oil based solid insulator; TBT } \\
\text { based anti-fouling paints would not be used on the } \\
\text { submerged surfaces of foundations. Instead, barnacles } \\
\text { and mussels attached to the foundation would be } \\
\text { removed by scraping if necessary; Adhere to specific } \\
\text { construction methods to minimize environmental impact; } \\
\text { A waste management plan must be in place prior to } \\
\text { construction; Insulate cables to reduce impact of } \\
\text { magnetic field; Monitor fish and cetaceans, including } \\
\text { cumulative impacts; Construction timed for when } \\
\text { juvenile fish are not present }\end{array}$ \\
\hline & $\begin{array}{l}\text { Organisms: } \\
\text { Benthic }\end{array}$ & $\begin{array}{l}\text { New habitat may } \\
\text { increase biodiversity } \\
\text { and number of } \\
\text { organisms; loss of } \\
\text { organisms during } \\
\text { construction or in } \\
\text { the event of } \\
\text { contamination; } \\
\text { disruption of } \\
\text { behavior from } \\
\text { electromagnetic } \\
\text { field; serve as } \\
\text { artificial reef }\end{array}$ & $\begin{array}{l}\text { Spatial impacts may } \\
\text { be more significant } \\
\text { during times of } \\
\text { spawning, } \\
\text { migration, feeding, } \\
\text { and construction }\end{array}$ & $\begin{array}{l}\text { Wind farms not allowed } \\
\text { in any special areas of } \\
\text { conservation/protection }\end{array}$ & $\begin{array}{l}\text { All oil filled equipment will be fully bundled to ensure no } \\
\text { spillage in the event of a leak or puncture in any vessels } \\
\text { or the offshore substation; power cables will use an } \\
\text { alternative non-oil based solid insulator; adhere to } \\
\text { specific construction methods to minimize environmental } \\
\text { impact, including seasonal restrictions on construction as } \\
\text { needed; a waste management plan must be in place prior } \\
\text { to construction; insulate cables to reduce impact of } \\
\text { magnetic field; monitor benthic ecology }\end{array}$ \\
\hline$\underline{\breve{u}}$ & $\begin{array}{l}\text { Commercial } \\
\text { Fisheries }\end{array}$ & $\begin{array}{l}\text { Physical occupation } \\
\text { of space; } \\
\text { entanglement of } \\
\text { gear; exclusion of } \\
\text { certain types of } \\
\text { fishing gear; } \\
\text { potential exclusion } \\
\text { of all fishing; } \\
\text { potential increase in } \\
\text { species diversity } \\
\text { and/or number of } \\
\text { fish; potential } \\
\text { increase of } \\
\text { commercially }\end{array}$ & $\begin{array}{l}\text { Impacts may be } \\
\text { greatest during } \\
\text { fishing seasons }\end{array}$ & $\begin{array}{l}\text { Avoid siting farm in most } \\
\text { important fishery } \\
\text { grounds for key species }\end{array}$ & $\begin{array}{l}\text { Scour protection must not obstruct fishing gear; to the } \\
\text { extent possible, all construction boat traffic must use } \\
\text { existing shipping routes; maintain open dialogue with } \\
\text { fishermen (during planning, construction, and operation) } \\
\text { to determine the safe operating practices required within } \\
\text { the site, and to minimize conflicts; local fishermen can } \\
\text { continue placing pots for whelk during the operational } \\
\text { period; provide appropriate financial compensation for } \\
\text { lost effort; trawling and anchoring not allowed in wind } \\
\text { farm; unauthorized vessels may not approach within } 35 \\
\text { meters of a turbine, or tie up to any part of the structure; } \\
\text { vessels of sufficiently small draft for the waters over the } \\
\text { sand bank are free to pass through the wind farm, } \\
\text { avoiding the 35m exclusion zone; boating (of any kind) is }\end{array}$ \\
\hline
\end{tabular}




\begin{tabular}{|c|c|c|c|}
\hline & $\begin{array}{l}\text { important species } \\
\text { due to refugia } \\
\text { (restrictions on } \\
\text { fishing effort) }\end{array}$ & & $\begin{array}{l}\text { prohibited in all of the country's wind farms; leisure and } \\
\text { fishing craft can move through the wind park during the } \\
\text { operational period }\end{array}$ \\
\hline Aquaculture & $\begin{array}{l}\text { Potential for } \\
\text { accommodating } \\
\text { aquaculture } \\
\text { activities }\end{array}$ & & \\
\hline Oil \& Gas & $\begin{array}{l}\text { Physical occupation } \\
\text { of space }\end{array}$ & $\begin{array}{l}\text { Not allowed in gas fields } \\
\text { (existing or proposed); } \\
\text { Wind and oil and gas } \\
\text { may co-exist and benefit } \\
\text { from shared } \\
\text { infrastructure }\end{array}$ & \\
\hline $\begin{array}{l}\text { Sand \& Gravel } \\
\text { Mining }\end{array}$ & $\begin{array}{l}\text { Physical occupation } \\
\text { of space }\end{array}$ & $\begin{array}{l}\text { Offshore wind not } \\
\text { allowed in existing sand } \\
\text { and gravel extraction } \\
\text { sites; extraction } \\
\text { generally not permitted } \\
\text { beyond } 12 \text { miles from } \\
\text { the coast, as this area } \\
\text { has been set aside for } \\
\text { wind farms. Wind farms } \\
\text { will always take priority } \\
\text { seaward of the } 12 \text { mile } \\
\text { zone; sand extraction is } \\
\text { not allowed in a zone } \\
\text { with a width of 500 } \\
\text { meters around offshore } \\
\text { platforms, wind } \\
\text { turbines, cables and }\end{array}$ & $\begin{array}{l}\text { Coordinate siting with identification of sand and gravel } \\
\text { resources }\end{array}$ \\
\hline
\end{tabular}




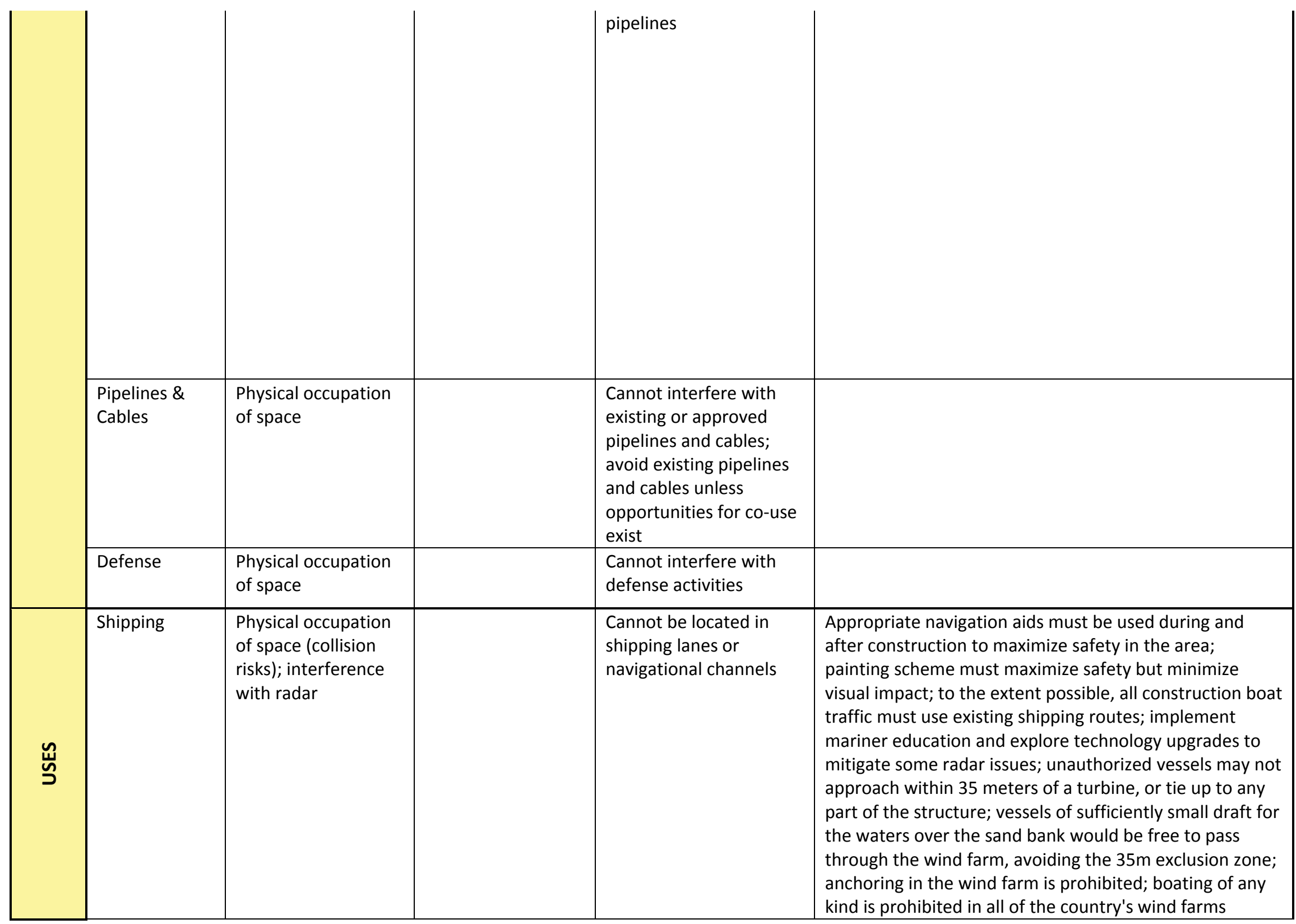




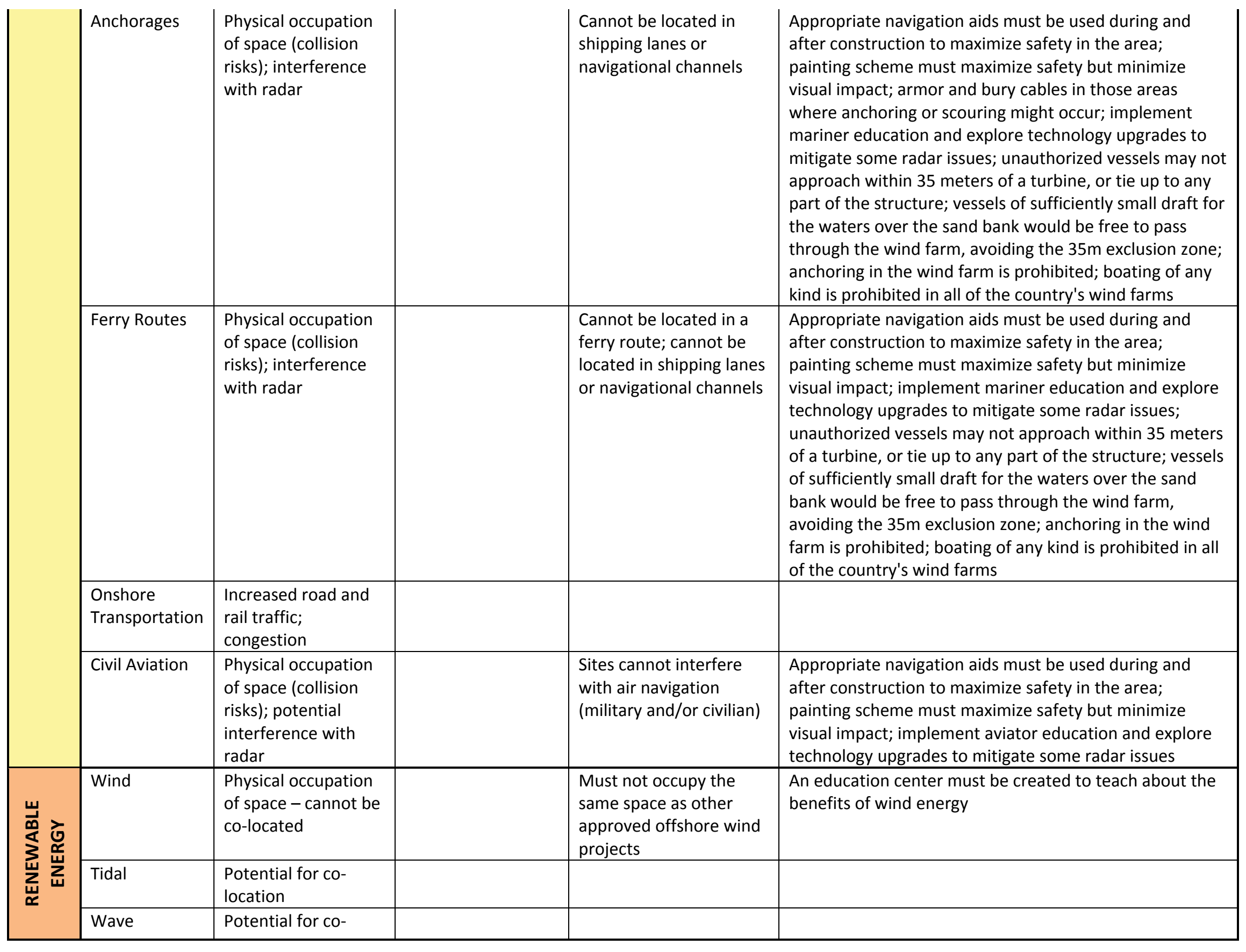

- 32 - DRAFT 


\begin{tabular}{|c|c|c|c|c|c|}
\hline & & location & & & \\
\hline 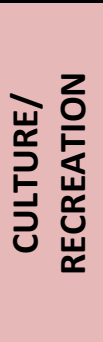 & $\begin{array}{l}\text { Sites of } \\
\text { Archeological } \\
\text { Significance }\end{array}$ & $\begin{array}{l}\text { Damage to } \\
\text { shipwreck/significant } \\
\text { site }\end{array}$ & & $\begin{array}{l}\text { Must avoid known } \\
\text { shipwrecks and } \\
\text { important sites; a 100m } \\
\text { exclusion zone is } \\
\text { required around known } \\
\text { wrecks; avoid } \\
\text { potentially significant } \\
\text { sites }\end{array}$ & \\
\hline \multirow[b]{3}{*}{ 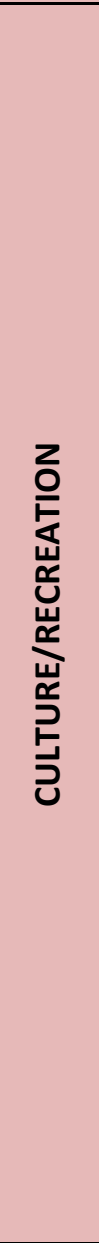 } & $\begin{array}{l}\text { Traditional } \\
\text { Rights }\end{array}$ & $\begin{array}{l}\text { Impairment of } \\
\text { various traditional } \\
\text { rights }\end{array}$ & & & Involve First Nations in planning process \\
\hline & Views & $\begin{array}{l}\text { Loss of sense of } \\
\text { place }\end{array}$ & & $\begin{array}{l}\text { Avoid areas of } \\
\text { outstanding natural } \\
\text { beauty; site a set } \\
\text { distance off shore to } \\
\text { avoid visual impacts }\end{array}$ & $\begin{array}{l}\text { Painting scheme must maximize safety but minimize } \\
\text { visual impact; orientate project so that its most narrow } \\
\text { edge faced shore, minimizing the visual impacts when } \\
\text { seen from land }\end{array}$ \\
\hline & Recreation & $\begin{array}{l}\text { Physical occupation } \\
\text { of space; } \\
\text { entanglement of } \\
\text { gear; collision risk; } \\
\text { visual impact to } \\
\text { onshore recreation; } \\
\text { water quality and } \\
\text { clarity; exclusion } \\
\text { zones; increase } \\
\text { diversity of species } \\
\text { and/or number of } \\
\text { fish; interference } \\
\text { with radar }\end{array}$ & $\begin{array}{l}\text { Impacts may be } \\
\text { greatest during } \\
\text { fishing and boating } \\
\text { seasons }\end{array}$ & $\begin{array}{l}\text { Identify and avoid } \\
\text { highest-use recreational } \\
\text { areas }\end{array}$ & $\begin{array}{l}\text { Scour protection must not obstruct fishing gear; } \\
\text { appropriate navigation aids must be used during and } \\
\text { after construction to maximize safety in the area; not } \\
\text { allowed to create exclusion zones preventing sailing } \\
\text { within wind farm site; leisure and fishing craft can move } \\
\text { through the wind park during operational period; } \\
\text { painting scheme must maximize safety but minimize } \\
\text { visual impact; all oil filled equipment would be fully } \\
\text { bundled to ensure no spillage in the event of a leak or } \\
\text { puncture in any vessels or the offshore substation; to the } \\
\text { extent possible, all construction boat traffic must use } \\
\text { existing shipping routes; local fishermen can continue } \\
\text { placing pots for whelk during the operational period; } \\
\text { unauthorized vessels may not approach within } 35 \text { meters } \\
\text { of the turbine, or tie up to any part of the structure; } \\
\text { vessels of sufficiently small draft for the waters over the } \\
\text { sand bank would be free to pass through the wind farm, } \\
\text { avoiding the } 35 \mathrm{~m} \text { exclusion zone; trawling and anchoring } \\
\text { prohibited in wind farm; boating of any kind is prohibited } \\
\text { in the wind farm; leisure and fishing craft can move } \\
\text { through the wind park during the operational period }\end{array}$ \\
\hline
\end{tabular}




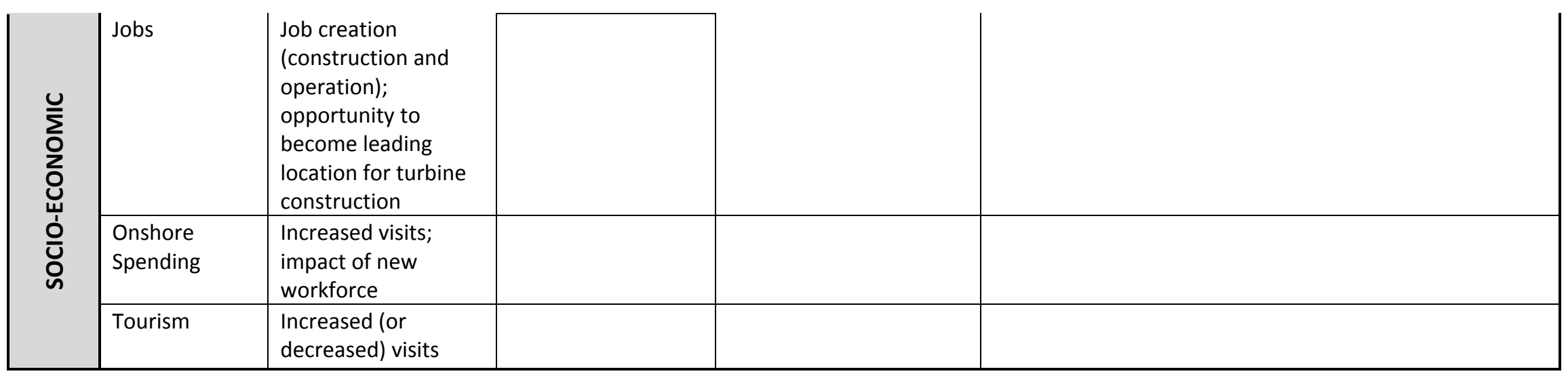




\section{SUBMARINE PIPELINE SITING CONSIDERATIONS}

UMass Boston Planning Team, May 2009. This table presents information from a number of international projects. This table should only be used as an initial guide. Additional research would be necessary to identify actual spatial and temporal considerations, standards, conditions, compensations, and mitigation measures for a specific project. This document does not represent positions or conclusions of the preparers, MOP, or EOEEA.

In addition to the information contained in this table, there are some fundamental conditions to consider when siting submarine pipelines. They include:

- The use of appropriate materials for depth and material being transported

- Appropriate substrate to support construction and operation

- Consistency with applicable planning goals and objectives

\begin{tabular}{|c|c|c|c|c|c|}
\hline & & $\begin{array}{l}\text { POTENTIAL } \\
\text { SPATIAL } \\
\text { CONSIDERATIONS } \\
\text { (May be limited to } \\
\text { the duration of the } \\
\text { project) }\end{array}$ & $\begin{array}{l}\text { POTENTIAL TEMPORAL } \\
\text { CONSIDERATIONS } \\
\text { (May be limited to the } \\
\text { duration of the project) }\end{array}$ & $\begin{array}{l}\text { EXAMPLES OF } \\
\text { SITING } \\
\text { STANDARDS }\end{array}$ & $\begin{array}{c}\text { EXAMPLES OF } \\
\text { COMPENSATION/MITIGATION/CONDITIONS }\end{array}$ \\
\hline \multirow{2}{*}{ 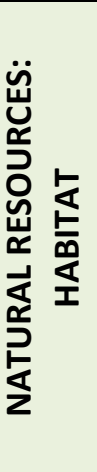 } & Habitat: Air & & $\begin{array}{l}\text { Minor air pollution } \\
\text { impacts expected from } \\
\text { vessels during } \\
\text { construction }\end{array}$ & $\begin{array}{l}\text { Avoid crossing areas } \\
\text { designated as } \\
\text { "protected" or } \\
\text { "environmentally } \\
\text { sensitive" }\end{array}$ & $\begin{array}{l}\text { Supervisor (Director of OEP) can change conditions of } \\
\text { FERC's Order, add new measures (including stopping } \\
\text { work), and other measures to assure compliance and } \\
\text { avoid/mitigate environmental impact; conduct } \\
\text { construction outside of the ozone protection period } \\
\text { (which runs from May } 15 \text { - September 15) }\end{array}$ \\
\hline & $\begin{array}{l}\text { Habitat: } \\
\text { Surface }\end{array}$ & $\begin{array}{l}\text { Gas contamination } \\
\text { from seepage or } \\
\text { rupture }\end{array}$ & & $\begin{array}{l}\text { Avoid crossing areas } \\
\text { designated as } \\
\text { "protected" or } \\
\text { "environmentally } \\
\text { sensitive" }\end{array}$ & $\begin{array}{l}\text { Supervisor (Director of OEP) can change conditions of } \\
\text { FERC's Order, add new measures (including stopping } \\
\text { work), and other measures to assure compliance and } \\
\text { avoid/mitigate environmental impact }\end{array}$ \\
\hline
\end{tabular}




\begin{tabular}{|c|c|c|c|c|}
\hline $\begin{array}{l}\text { Habitat: Water } \\
\text { Column }\end{array}$ & $\begin{array}{l}\text { Gas contamination } \\
\text { from seepage or } \\
\text { rupture; change in } \\
\text { water flows }\end{array}$ & $\begin{array}{l}\text { Increased pollution during } \\
\text { construction and pre- } \\
\text { construction; } \\
\text { contaminated sediment } \\
\text { suspended in water } \\
\text { column; running into } \\
\text { pockets of gas }\end{array}$ & $\begin{array}{l}\text { Avoid crossing areas } \\
\text { designated as } \\
\text { "protected" or } \\
\text { "environmentally } \\
\text { sensitive" }\end{array}$ & $\begin{array}{l}\text { Clear sediment, mud, and construction refuse post- } \\
\text { construction to restore natural flow regime; conduct } \\
\text { geotechnical investigations and analyses prior to } \\
\text { construction in order to determine any design features } \\
\text { or mitigation measures to avoid leaks from earthquakes } \\
\text { or soil liquefaction; use non-toxic anti-fouling products; } \\
\text { employ BMPs to reduce pollution from spills; monitor } \\
\text { water quality; supervisor (Director of OEP) can change } \\
\text { conditions of FERC's Order, add new measures } \\
\text { (including stopping work), and other measures to assure } \\
\text { compliance and avoid/mitigate environmental impact }\end{array}$ \\
\hline $\begin{array}{l}\text { Habitat: } \\
\text { Benthic }\end{array}$ & $\begin{array}{l}\text { Habitat created by } \\
\text { new pipes; } \\
\text { accelerated erosion; } \\
\text { gas contamination } \\
\text { from seepage or } \\
\text { rupture }\end{array}$ & $\begin{array}{l}\text { Change in slope runoff } \\
\text { dynamics during } \\
\text { construction; increased } \\
\text { turbidity during } \\
\text { construction and pre } \\
\text { construction; } \\
\text { contaminated sediment } \\
\text { disturbed; habitat loss } \\
\text { due to reduced sunlight } \\
\text { during periods of high } \\
\text { water turbidity; minor } \\
\text { pollution from release of } \\
\text { metal particles from anti- } \\
\text { corrosion nodes; } \\
\text { temporary habitat loss } \\
\text { due to anchors, pipe- } \\
\text { laying, and other } \\
\text { activities; physical } \\
\text { alteration of the seabed; } \\
\text { running into pockets of } \\
\text { gas }\end{array}$ & $\begin{array}{l}\text { Avoid crossing areas } \\
\text { designated as } \\
\text { "protected" or } \\
\text { "environmentally } \\
\text { sensitive" }\end{array}$ & $\begin{array}{l}\text { Clear sediment, mud, and construction refuse post- } \\
\text { construction to restore natural flow regime; depth of } \\
\text { pipe burial is determined by taking into account the } \\
\text { possibility of movement in the sea bed and the } \\
\text { requirements of future dredging works; conduct } \\
\text { geotechnical investigations and analyses prior to } \\
\text { construction in order to determine any design features } \\
\text { or mitigation measures to avoid leaks from earthquakes } \\
\text { or soil liquefaction; use mid-line buoys on anchor cables } \\
\text { or use a dynamically positioned lay barge to reduce } \\
\text { anchor cable sweep; develop and file plans to backfill } \\
\text { and monitor trenched area prior to construction; } \\
\text { employ BMPs and monitoring to minimize scouring; } \\
\text { supervisor (Director of OEP) can change conditions of } \\
\text { FERC's Order, add new measures (including stopping } \\
\text { work), and other measures to assure compliance and } \\
\text { avoid/mitigate environmental impact; use native type of } \\
\text { sediment (e.g. sandy instead of rocky) to backfill } \\
\text { trenches in order to reduce likelihood of providing new } \\
\text { habitat for colonization by invasive species }\end{array}$ \\
\hline
\end{tabular}




\begin{tabular}{|c|c|c|c|c|c|}
\hline \multirow{3}{*}{ 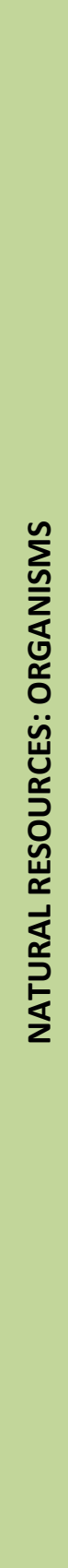 } & Organisms: Air & & $\begin{array}{l}\text { Munitions clearing can } \\
\text { impact birds; turbidity can } \\
\text { impact diving birds' } \\
\text { feeding }\end{array}$ & $\begin{array}{l}\text { Avoid crossing areas } \\
\text { designated as } \\
\text { "protected" or } \\
\text { "environmentally } \\
\text { sensitive" }\end{array}$ & $\begin{array}{l}\text { Conduct studies to identify possible munitions and } \\
\text { follow BMP to deal with them; supervisor (Director of } \\
\text { OEP) can change conditions of FERC's Order, add new } \\
\text { measures (including stopping work), and other } \\
\text { measures to assure compliance and avoid/mitigate } \\
\text { environmental impact; develop and implement lighting } \\
\text { plan to reduce impacts on avian species, marine } \\
\text { mammals, and fish; use monitors during construction to } \\
\text { identify listed species; avoid listed species and marine } \\
\text { mammals during construction; identify appropriate } \\
\text { mitigation measures as they relate to harassment } \\
\text { thresholds for construction activities and noise }\end{array}$ \\
\hline & $\begin{array}{l}\text { Organisms: } \\
\text { Surface }\end{array}$ & $\begin{array}{l}\text { Gas contamination } \\
\text { from seepage or } \\
\text { rupture }\end{array}$ & $\begin{array}{l}\text { Munitions clearing would } \\
\text { impact animals } \\
\text { throughout the water } \\
\text { column; increased } \\
\text { construction noise may } \\
\text { harm fish and marine } \\
\text { mammals }\end{array}$ & $\begin{array}{l}\text { Avoid crossing areas } \\
\text { designated as } \\
\text { "protected" or } \\
\text { "environmentally } \\
\text { sensitive" }\end{array}$ & $\begin{array}{l}\text { Conduct studies to identify possible munitions and } \\
\text { follow BMP to deal with them; avoid the use of high- } \\
\text { speed vessels during construction; use monitors during } \\
\text { construction to identify listed species; avoid listed } \\
\text { species and marine mammals during construction } \\
\text { (develop a vessel strike avoidance plan); supervisor } \\
\text { (Director of OEP) can change conditions of FERC's Order, } \\
\text { add new measures (including stopping work), and other } \\
\text { measures to assure compliance and avoid/mitigate } \\
\text { environmental impact; develop and implement lighting } \\
\text { plan to reduce impacts on avian species, marine } \\
\text { mammals, and fish; identify appropriate mitigation } \\
\text { measures as they relate to harassment thresholds for } \\
\text { construction activities and noise }\end{array}$ \\
\hline & $\begin{array}{l}\text { Organisms: } \\
\text { Water Column }\end{array}$ & $\begin{array}{l}\text { Gas contamination } \\
\text { from seepage or } \\
\text { rupture; increase in } \\
\text { biomass (of } \\
\text { macrozoobenthos } \\
\text { for example) from } \\
\text { gas in water; impact } \\
\text { to EFH and EFH- } \\
\text { managed species }\end{array}$ & $\begin{array}{l}\text { Increased noise may harm } \\
\text { fish and marine mammals; } \\
\text { increased vibrations may } \\
\text { harm fish and marine } \\
\text { mammals; noise from gas } \\
\text { moving through pipe } \\
\text { might require an } \\
\text { adjustment phase; } \\
\text { munitions clearing in } \\
\text { some sites could cause } \\
\text { tissue damage to some } \\
\text { fish }\end{array}$ & $\begin{array}{l}\text { Avoid crossing areas } \\
\text { designated as } \\
\text { "protected" or } \\
\text { "environmentally } \\
\text { sensitive" }\end{array}$ & $\begin{array}{l}\text { Conduct studies to identify possible munitions and } \\
\text { follow BMP to deal with them; time construction to } \\
\text { avoid harming sea turtles; use monitors during } \\
\text { construction to identify listed species; avoid listed } \\
\text { species and marine mammals during construction } \\
\text { (develop a vessel strike avoidance plan); supervisor } \\
\text { (Director of OEP) can change conditions of FERC's Order, } \\
\text { add new measures (including stopping work), and other } \\
\text { measures to assure compliance and avoid/mitigate } \\
\text { environmental impact; identify appropriate mitigation } \\
\text { measures as they relate to harassment thresholds for } \\
\text { construction activities and noise; develop and } \\
\text { implement lighting plan to reduce impacts on avian } \\
\text { species, marine mammals, and fish }\end{array}$ \\
\hline
\end{tabular}




\begin{tabular}{|c|c|c|c|c|c|}
\hline & $\begin{array}{l}\text { Organisms: } \\
\text { Benthic }\end{array}$ & $\begin{array}{l}\text { Gas contamination } \\
\text { from seepage or } \\
\text { rupture; increase in } \\
\text { biomass (of } \\
\text { macrozoobenthos } \\
\text { for example) from } \\
\text { gas in water; impact } \\
\text { to EFH and EFH- } \\
\text { managed species }\end{array}$ & $\begin{array}{l}\text { Increased noise may harm } \\
\text { fish and marine mammals; } \\
\text { smothering from } \\
\text { construction activities; } \\
\text { loss due to reduced } \\
\text { sunlight during periods of } \\
\text { high water turbidity; } \\
\text { munitions clearing would } \\
\text { impact animals } \\
\text { throughout the water } \\
\text { column }\end{array}$ & $\begin{array}{l}\text { Avoid crossing areas } \\
\text { designated as } \\
\text { "protected" or } \\
\text { "environmentally } \\
\text { sensitive" }\end{array}$ & $\begin{array}{l}\text { Conduct studies to identify possible munitions and } \\
\text { follow BMP to deal with them; use mid-line buoys on } \\
\text { anchor cables or use a dynamically positioned lay barge } \\
\text { to reduce anchor cable sweep; use native type of } \\
\text { sediment (e.g. sandy instead of rocky) to backfill } \\
\text { trenches in order to reduce likelihood of providing new } \\
\text { habitat for colonization by invasive species; supervisor } \\
\text { (Director of OEP) can change conditions of FERC's Order, } \\
\text { add new measures (including stopping work), and other } \\
\text { measures to assure compliance and avoid/mitigate } \\
\text { environmental impact; use } 3 \text { inch steel-reinforced } \\
\text { concrete around pipeline to reduce impacts from anchor } \\
\text { strikes }\end{array}$ \\
\hline \multirow[t]{5}{*}{ 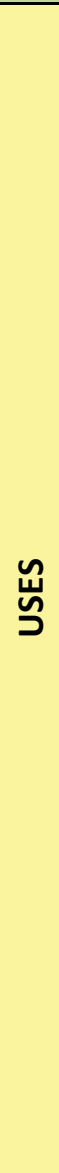 } & $\begin{array}{l}\text { Commercial } \\
\text { Fisheries }\end{array}$ & $\begin{array}{l}\text { Displacement of } \\
\text { fishing activities } \\
\text { within exclusion } \\
\text { zone around } \\
\text { pipeline; damage to } \\
\text { fishing gear }\end{array}$ & $\begin{array}{l}\text { Displacement of fishing } \\
\text { activity and navigation of } \\
\text { fishing vessels during } \\
\text { construction and } \\
\text { munitions clearing; } \\
\text { increased vessel traffic } \\
\text { during construction could } \\
\text { increase congestion on } \\
\text { the water; the use of } \\
\text { exclusion zones around } \\
\text { construction/maintenance } \\
\text { vessels may increase } \\
\text { congestion on the water; } \\
\text { impacts may be greatest } \\
\text { during certain fishing } \\
\text { seasons }\end{array}$ & $\begin{array}{l}\text { Site route to } \\
\text { minimize impact to } \\
\text { commercial fisheries }\end{array}$ & $\begin{array}{l}\text { Monitor to determine impact of pipelines on presence } \\
\text { (either increased or decreased) of fish; mitigation } \\
\text { measures may be arranged with displaced fishermen; } \\
\text { add pipeline to navigational charts; vessels prohibited } \\
\text { from anchoring along pipeline corridor; pipe buried to } \\
\text { avoid anchor strikes; consider a thicker pipe wall, thicker } \\
\text { concrete coating, rock armor, or concrete slabs to } \\
\text { protect against harm from anchoring; prior to } \\
\text { construction, complete final compensation agreements } \\
\text { with commercial fishermen impacted by the safety and } \\
\text { security zones; a mechanism will be developed to } \\
\text { compensate fishermen for gear damaged as a result of } \\
\text { the pipeline and related LNG project }\end{array}$ \\
\hline & Aquaculture & & & & \\
\hline & Oil \& Gas & $\begin{array}{l}\text { Will likely be co- } \\
\text { located }\end{array}$ & & & \\
\hline & $\begin{array}{l}\text { Sand \& Gravel } \\
\text { Mining }\end{array}$ & & & & $\begin{array}{l}\text { Depth of pipe burial is determined by taking into } \\
\text { account the possibility of movement in the sea bed and } \\
\text { the requirements of future dredging works; sand } \\
\text { extraction is not permitted in a zone with a width of } 500 \\
\text { meters around pipelines }\end{array}$ \\
\hline & Cables & $\begin{array}{l}\text { May damage } \\
\text { existing utilities; } \\
\text { may be co-located }\end{array}$ & & $\begin{array}{l}\text { Site route to } \\
\text { minimize impact to } \\
\text { existing cables }\end{array}$ & $\begin{array}{l}\text { In consultation with utility companies having submarine } \\
\text { pipes or cables, develop site-specific construction plans } \\
\text { to avoid impacts to those utilities }\end{array}$ \\
\hline
\end{tabular}

- 38 - DRAFT 


\begin{tabular}{|c|c|c|c|c|c|}
\hline & Pipelines & $\begin{array}{l}\text { May damage } \\
\text { existing utilities; } \\
\text { may be co-located }\end{array}$ & & $\begin{array}{l}\text { Site route to } \\
\text { minimize impact to } \\
\text { existing pipes }\end{array}$ & $\begin{array}{l}\text { In consultation with utility companies having submarine } \\
\text { pipes or cables, develop site-specific construction plans } \\
\text { to avoid impacts to those utilities }\end{array}$ \\
\hline & Defense & & & $\begin{array}{l}\text { Site route to } \\
\text { minimize impact to } \\
\text { military activities; } \\
\text { site route to avoid } \\
\text { old munitions } \\
\text { dumping sites }\end{array}$ & \\
\hline & Shipping & $\begin{array}{l}\text { Displacement of } \\
\text { shipping activities } \\
\text { within exclusion } \\
\text { zone around } \\
\text { pipeline }\end{array}$ & $\begin{array}{l}\text { Displacement of shipping } \\
\text { activities during } \\
\text { construction and } \\
\text { munitions clearing; } \\
\text { increased vessel traffic } \\
\text { during construction could } \\
\text { increase congestion on } \\
\text { the water; the use of } \\
\text { exclusion zones around } \\
\text { construction/maintenance } \\
\text { vessels may increase } \\
\text { congestion on the water }\end{array}$ & $\begin{array}{l}\text { Site route to } \\
\text { minimize impact to } \\
\text { shipping }\end{array}$ & $\begin{array}{l}\text { Add pipeline to navigational charts; vessels prohibited } \\
\text { from anchoring along pipeline corridor; pipe buried to } \\
\text { avoid anchor strikes; consider a thicker pipe wall, thicker } \\
\text { concrete coating, rock armor, or concrete slabs to } \\
\text { protect against harm from anchoring; } 3 \text { inch steel- } \\
\text { reinforced concrete around pipeline to reduce impacts } \\
\text { from anchor strikes }\end{array}$ \\
\hline & Anchorages & $\begin{array}{l}\text { Anchors may } \\
\text { damage pipelines }\end{array}$ & & & $\begin{array}{l}\text { Vessels prohibited from anchoring along pipeline } \\
\text { corridor; pipe buried to avoid anchor strikes; consider a } \\
\text { thicker pipe wall, thicker concrete coating, rock armor, } \\
\text { or concrete slabs to protect against harm from } \\
\text { anchoring; } 3 \text { inch steel-reinforced concrete around } \\
\text { pipeline to reduce impacts from anchor strikes }\end{array}$ \\
\hline 岃 & Ferry Routes & & $\begin{array}{l}\text { Increased vessel traffic } \\
\text { during construction could } \\
\text { increase congestion on } \\
\text { the water; the use of } \\
\text { exclusion zones around } \\
\text { construction/maintenance } \\
\text { vessels may increase } \\
\text { congestion on the water } \\
\end{array}$ & & $\begin{array}{l}\text { Add pipeline to navigational charts; consider a thicker } \\
\text { pipe wall, thicker concrete coating, rock armor, or } \\
\text { concrete slabs to protect against harm from anchoring }\end{array}$ \\
\hline & $\begin{array}{l}\text { Onshore } \\
\text { Transportation }\end{array}$ & & $\begin{array}{l}\text { Transportation of } \\
\text { construction materials } \\
\text { may impact roadway } \\
\text { congestion }\end{array}$ & & $\begin{array}{l}\text { Use rail transportation as much as possible to reduce } \\
\text { impact to roadways/traffic patterns }\end{array}$ \\
\hline
\end{tabular}




\begin{tabular}{|c|c|c|c|c|c|}
\hline & Civil Aviation & & & & \\
\hline \multirow{3}{*}{ 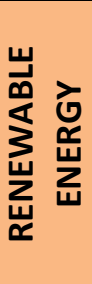 } & Wind & & & $\begin{array}{l}\text { Site route to } \\
\text { minimize impact to } \\
\text { existing offshore } \\
\text { wind projects }\end{array}$ & \\
\hline & Tidal & & & & \\
\hline & Wave & & & & \\
\hline \multirow{4}{*}{ 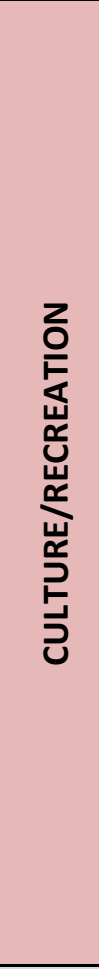 } & \begin{tabular}{|l|} 
Sites of \\
Archeological \\
Significance
\end{tabular} & $\begin{array}{l}\text { Significant and } \\
\text { potentially } \\
\text { significant sites may } \\
\text { be damaged during } \\
\text { construction } \\
\end{array}$ & & $\begin{array}{l}\text { Site route to } \\
\text { minimize impact to } \\
\text { archeological } \\
\text { resources }\end{array}$ & $\begin{array}{l}\text { Conduct remote sensing surveys to detect archeological } \\
\text { sites; use mid-line buoys on all anchor cables to reduce } \\
\text { anchor cable sweep; significant and potentially } \\
\text { significant sites will have a } 100 \mathrm{ft} \text {. buffer around them }\end{array}$ \\
\hline & $\begin{array}{l}\text { Traditional } \\
\text { Rights }\end{array}$ & & & & \\
\hline & Views & & $\begin{array}{l}\text { Vessels and equipment } \\
\text { will have minor impacts } \\
\text { on views during } \\
\text { construction }\end{array}$ & & \\
\hline & Recreation & & $\begin{array}{l}\text { Increased vessel traffic } \\
\text { during construction could } \\
\text { increase congestion on } \\
\text { the water; the use of } \\
\text { exclusion zones around } \\
\text { construction/maintenance } \\
\text { vessels may increase } \\
\text { congestion on the water; } \\
\text { impacts may be greatest } \\
\text { during fishing and boating } \\
\text { seasons }\end{array}$ & $\begin{array}{l}3 \text { inch steel- } \\
\text { reinforced concrete } \\
\text { around pipeline to } \\
\text { reduce impacts from } \\
\text { anchor strikes }\end{array}$ & $\begin{array}{l}\text { Add pipeline to navigational charts; vessels prohibited } \\
\text { from anchoring along pipeline corridor; pipe buried to } \\
\text { avoid anchor strikes; consider a thicker pipe wall, thicker } \\
\text { concrete coating, rock armor, or concrete slabs to } \\
\text { protect against harm from anchoring }\end{array}$ \\
\hline \multirow{3}{*}{ 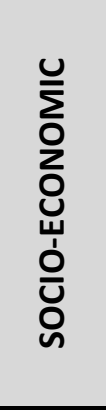 } & Jobs & & $\begin{array}{l}\text { Construction jobs would } \\
\text { be created (and some } \\
\text { maintenance jobs) }\end{array}$ & & \\
\hline & $\begin{array}{l}\text { Onshore } \\
\text { Spending }\end{array}$ & & & & $\begin{array}{l}\text { LNG pipe and terminal operator would either pay taxes } \\
\text { or an annual fee to communities during the life of the } \\
\text { project }\end{array}$ \\
\hline & Tourism & & & $\begin{array}{l}\text { Site route to } \\
\text { minimize impact to } \\
\text { tourism activities }\end{array}$ & \\
\hline
\end{tabular}




\section{SAND AND GRAVEL SITING CONSIDERATIONS}

UMass Boston Planning Team, May 2009. This table presents information from a number of international projects. This table should only be used as an initial guide. Additional research would be necessary to identify actual spatial and temporal considerations, standards, conditions, compensations, and mitigation measures for a specific project. This document does not represent positions or conclusions of the preparers, MOP, or EOEEA.

In addition to the information contained in this table, there are some fundamental conditions to consider when siting sand and gravel extraction projects. They include:

- Appropriate sediment type(s) and water depth

- Consistency with applicable planning goals and objectives.

\begin{tabular}{|c|c|c|c|c|c|}
\hline & & $\begin{array}{c}\text { POTENTIAL } \\
\text { SPATIAL } \\
\text { CONSIDERATIONS } \\
\text { (May be limited to } \\
\text { the duration of the } \\
\text { project) }\end{array}$ & $\begin{array}{c}\text { POTENTIAL } \\
\text { TEMPORAL } \\
\text { CONSIDERATIONS } \\
\text { (May be limited to } \\
\text { the duration of the } \\
\text { project) }\end{array}$ & $\begin{array}{l}\text { EXAMPLES OF SITING } \\
\text { STANDARDS }\end{array}$ & $\begin{array}{c}\text { EXAMPLES OF } \\
\text { COMPENSATION/MITIGATION/CONDITIONS }\end{array}$ \\
\hline \multirow{2}{*}{ 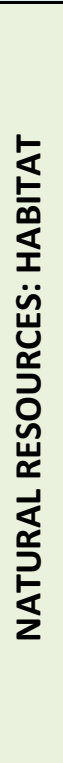 } & Habitat: Air & $\begin{array}{l}\text { May impact air } \\
\text { quality }\end{array}$ & $\begin{array}{l}\text { Lighting during } \\
\text { mining may disrupt } \\
\text { animal behavior; } \\
\text { contamination from } \\
\text { mining equipment }\end{array}$ & $\begin{array}{l}\text { Mining areas should not be in } \\
\text { natural parks or biological } \\
\text { protected areas; mining only } \\
\text { allowed in areas that were } \\
\text { previously identified through an } \\
\text { impact assessment; mining } \\
\text { should not influence fragile } \\
\text { ecosystems }\end{array}$ & $\begin{array}{l}\text { Projects may be required to use environmentally } \\
\text { friendly extraction technologies; lighting impacts } \\
\text { during construction should be minimized through } \\
\text { reduction, shielding, lowering and appropriate } \\
\text { placement; from May-October lighting on barges } \\
\text { operating } 3 \mathrm{nmi} \text { from sea turtle nesting beaches } \\
\text { must use the minimum lighting necessary to comply } \\
\text { with USCG and OSHA requirements; habitat mapping } \\
\text { may be required }\end{array}$ \\
\hline & $\begin{array}{l}\text { Habitat: } \\
\text { Surface }\end{array}$ & $\begin{array}{l}\text { Alterations to water } \\
\text { circulation, current } \\
\text { speeds, and normal } \\
\text { water-level } \\
\text { fluctuations }\end{array}$ & $\begin{array}{l}\text { Lighting during } \\
\text { mining may disrupt } \\
\text { animal behavior; } \\
\text { contamination from } \\
\text { mining equipment }\end{array}$ & $\begin{array}{l}\text { Mining areas should not be in } \\
\text { natural parks or biological } \\
\text { protected areas; mining only } \\
\text { allowed in areas that were } \\
\text { previously identified through an } \\
\text { impact assessment; mining } \\
\text { should not influence fragile } \\
\text { ecosystems }\end{array}$ & $\begin{array}{l}\text { Projects may be required to use environmentally } \\
\text { friendly extraction technologies; lighting impacts } \\
\text { during construction should be minimized through } \\
\text { reduction, shielding, lowering and appropriate } \\
\text { placement; from May-October lighting on barges } \\
\text { operating } 3 \mathrm{nmi} \text { from sea turtle nesting beaches } \\
\text { must use the minimum lighting necessary to comply } \\
\text { with USCG and OSHA requirements; habitat mapping } \\
\text { may be required }\end{array}$ \\
\hline
\end{tabular}




\begin{tabular}{|c|c|c|c|c|c|}
\hline & $\begin{array}{l}\text { Habitat: Water } \\
\text { Column }\end{array}$ & $\begin{array}{l}\text { Alterations to water } \\
\text { circulation, current } \\
\text { speeds, and normal } \\
\text { water-level } \\
\text { fluctuations }\end{array}$ & $\begin{array}{l}\text { Increased } \\
\text { concentrations of } \\
\text { suspended } \\
\text { particulates/turbidity; } \\
\text { impact on primary } \\
\text { production; lighting } \\
\text { during mining may } \\
\text { disrupt animal } \\
\text { behavior; } \\
\text { contamination from } \\
\text { mining equipment }\end{array}$ & $\begin{array}{l}\text { Mining areas should not be in } \\
\text { natural parks or biological } \\
\text { protected areas; mining only } \\
\text { allowed in areas that were } \\
\text { previously identified through an } \\
\text { impact assessment; mining } \\
\text { should not influence fragile } \\
\text { ecosystems }\end{array}$ & $\begin{array}{l}\text { Special attention is given to turbidity plumes and } \\
\text { their consequences for primary production, benthos, } \\
\text { fish, and birds; license conditions may specify limits } \\
\text { for spills; projects may be required to use } \\
\text { environmentally friendly extraction technologies; } \\
\text { lighting impacts during construction should be } \\
\text { minimized through reduction, shielding, lowering } \\
\text { and appropriate placement; take necessary } \\
\text { precautions to prevent discharge of oil and } \\
\text { hazardous materials; from May-October lighting on } \\
\text { barges operating } 3 \text { nmi from sea turtle nesting } \\
\text { beaches must use the minimum lighting necessary to } \\
\text { comply with USCG and OSHA requirements; habitat } \\
\text { mapping may be required }\end{array}$ \\
\hline 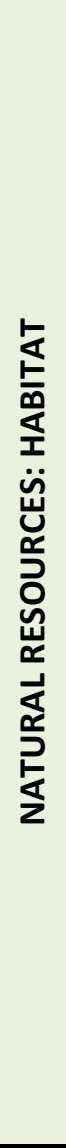 & $\begin{array}{l}\text { Habitat: } \\
\text { Benthic }\end{array}$ & $\begin{array}{l}\text { Substrate impacts } \\
\text { (including } \\
\text { deposition outside } \\
\text { the extraction area, } \\
\text { sediment } \\
\text { transport); } \\
\text { impairment or } \\
\text { destruction of } \\
\text { habitat; } \\
\text { recolonization of } \\
\text { fauna; removal of } \\
\text { contaminated } \\
\text { sediment }\end{array}$ & $\begin{array}{l}\text { Increased } \\
\text { concentrations of } \\
\text { suspended } \\
\text { particulates/turbidity }\end{array}$ & $\begin{array}{l}\text { Mining areas should not be in } \\
\text { natural parks or biological } \\
\text { protected areas; mining only } \\
\text { allowed in areas that were } \\
\text { previously identified through an } \\
\text { impact assessment; mining } \\
\text { should not influence fragile } \\
\text { ecosystems; deep sand } \\
\text { extraction is only allowable } \\
\text { further than } 2 \text { kilometers out } \\
\text { past the } 20 \text { meter isobaths; } \\
\text { projects at least } 3 \text { nautical } \\
\text { miles from shore, grassland, or } \\
\text { phanerogamae; buffer areas } \\
\text { (400 or } 600 \text { feet wide) should } \\
\text { be placed around all hard- } \\
\text { bottomed areas located } \\
\text { within/near borrow areas, and } \\
\text { no excavation or mooring } \\
\text { should be allowed in these } \\
\text { areas }\end{array}$ & $\begin{array}{l}\text { If extraction volume exceeds } 10 \text { million meters } \\
\text { cubed, or an extraction area exceeds } 500 \text { hectares, } \\
\text { an environmental impact assessment is required; an } \\
\text { ecological study is required when the intended } \\
\text { extraction depth exceeds } 2 \text { meters; standard sand } \\
\text { extraction permits (for extraction down to depths of } \\
2 \text { meters) are issued on the basis of a generic } \\
\text { environmental impact report; knowledge of physical } \\
\text { and ecological response of the sand pits is needed to } \\
\text { assess their environmental impact; projects may be } \\
\text { required to use environmentally friendly extraction } \\
\text { technologies; coastal supplementation, carried out } \\
\text { under the Flood Defense Act, does not need a } \\
\text { permit; environmental assessment report is } \\
\text { required, often concentrating on the production of } \\
\text { turbid plumes and deposition of sand or finer- } \\
\text { grained sediment on the seabed outside the } \\
\text { extraction area. Includes a description of existing } \\
\text { environment and of impacts of proposed dredging } \\
\text { compared with alternatives; monitoring of mining } \\
\text { pits, nearby beaches, nearshore reefs, and hard } \\
\text { bottom areas; typical aspects investigated as part of } \\
\text { an environmental impact assessment include: spill } \\
\text { and spreading of fine sediment during dredging, } \\
\text { extension and thickness of deposition area, impact } \\
\text { on marine flora and fauna, and description of } \\
\text { existing environmental conditions and of the impacts }\end{array}$ \\
\hline
\end{tabular}

- 42 - DRAFT 


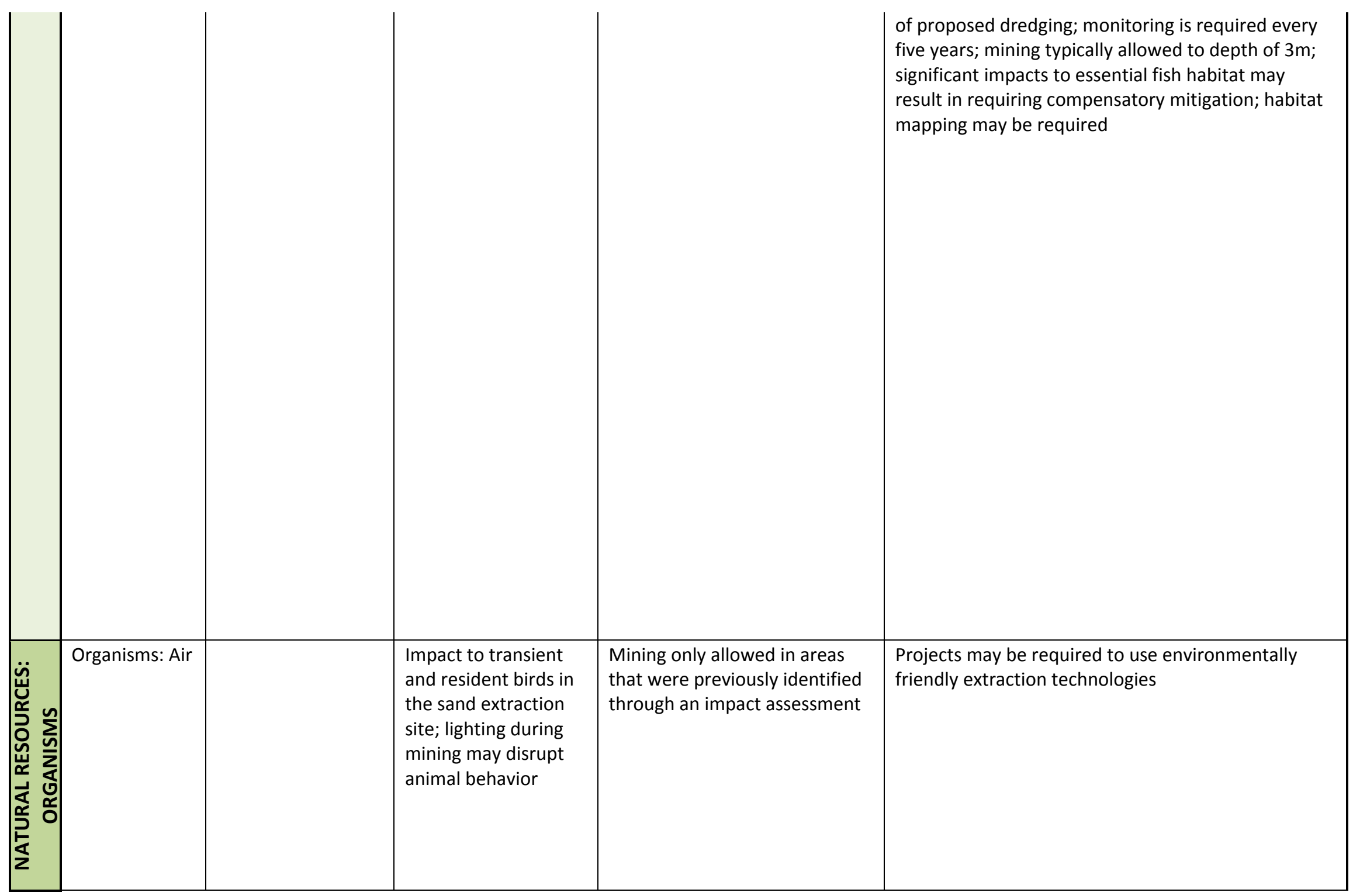




\begin{tabular}{|c|c|c|c|c|c|}
\hline 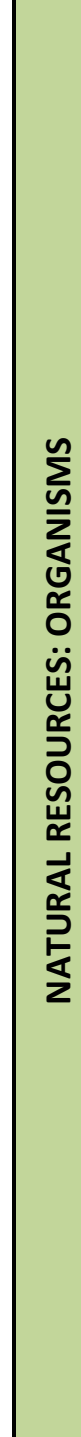 & $\begin{array}{l}\text { Organisms: } \\
\text { Surface }\end{array}$ & $\begin{array}{l}\text { Incidental take of } \\
\text { organisms }\end{array}$ & $\begin{array}{l}\text { Disruption of } \\
\text { spawning, feeding, } \\
\text { and migratory areas; } \\
\text { lighting during mining } \\
\text { may disrupt animal } \\
\text { behavior }\end{array}$ & $\begin{array}{l}\text { Mining areas should not be in } \\
\text { natural parks or biological } \\
\text { protected areas; mining only } \\
\text { allowed in areas that were } \\
\text { previously identified through an } \\
\text { impact assessment }\end{array}$ & $\begin{array}{l}\text { Projects may be required to use environmentally } \\
\text { friendly extraction technologies; projects may not } \\
\text { exceed the authorized incidental take limits on } \\
\text { endangered and threatened species established by } \\
\text { NOAA's SE Regional Office Protected Resource } \\
\text { Division's Regional Biological Opinion, and formal } \\
\text { consultation is required when } 75 \% \text { of the authorized } \\
\text { incidental take level is reached; incidental takes must } \\
\text { be reported; monitors must be used when in areas } \\
\text { where, and during seasons in which sea turtles are } \\
\text { present; a specified \% of the dredged material must } \\
\text { be screened and observed for beach nourishment } \\
\text { activities during the sea turtle season; hopper } \\
\text { dredges must be equipped with sea turtle deflecting } \\
\text { dragheads during months where sea turtles are } \\
\text { present; use BMPs to prevent injury to turtles; } \\
\text { dredging within right whale critical habitat from } \\
\text { December-March must follow the protocol } \\
\text { established within the Early Warning System; whale } \\
\text { observers must be on board to conduct daytime } \\
\text { observations between December and March; during } \\
\text { daylight, operators must take steps to avoid whales; } \\
\text { during evening hours or other times of limited } \\
\text { visibility (fog, sea conditions), the dredge must be } \\
\text { slowed to } 5 \text { knots or less when transiting between } \\
\text { areas if whales have been spotted within } 15 \text { nm of } \\
\text { the vessel's path within the previous } 24 \text { hours; } \\
\text { lighting impacts during construction should be } \\
\text { minimized through reduction, shielding, lowering } \\
\text { and appropriate placement; from May-October } \\
\text { lighting on barges operating } 3 \text { nmi from sea turtle } \\
\text { nesting beaches must use the minimum lighting } \\
\text { necessary to comply with USCG and OSHA } \\
\text { requirements; species monitoring may be required }\end{array}$ \\
\hline
\end{tabular}




\begin{tabular}{|c|c|c|c|c|c|}
\hline 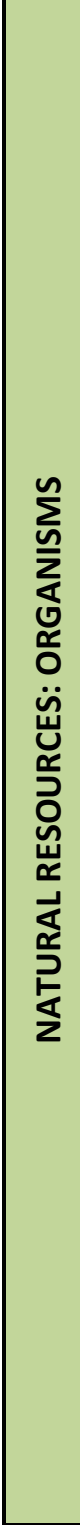 & $\begin{array}{l}\text { Organisms: } \\
\text { Water Column }\end{array}$ & $\begin{array}{l}\text { Incidental take of } \\
\text { organisms }\end{array}$ & $\begin{array}{l}\text { Disruption of } \\
\text { spawning, feeding, } \\
\text { and migratory areas; } \\
\text { lighting during mining } \\
\text { may disrupt animal } \\
\text { behavior }\end{array}$ & $\begin{array}{l}\text { Mining areas should not be in } \\
\text { natural parks or biological } \\
\text { protected areas; mining only } \\
\text { allowed in areas that were } \\
\text { previously identified through an } \\
\text { impact assessment }\end{array}$ & $\begin{array}{l}\text { Projects may be required to use environmentally } \\
\text { friendly extraction technologies; projects may not } \\
\text { exceed the authorized incidental take limits on } \\
\text { endangered and threatened species established by } \\
\text { NOAA's SE Regional Office Protected Resource } \\
\text { Division's Regional Biological Opinion, and formal } \\
\text { consultation is required when } 75 \% \text { of the authorized } \\
\text { incidental take level is reached; incidental takes must } \\
\text { be reported; monitors must be used when in areas } \\
\text { where, and during seasons in which sea turtles are } \\
\text { present; a specified \% of the dredged material must } \\
\text { be screened and observed for beach nourishment } \\
\text { activities during the sea turtle season; hopper } \\
\text { dredges must be equipped with sea turtle deflecting } \\
\text { dragheads during months where sea turtles are } \\
\text { present; use BMPs to prevent injury to turtles; } \\
\text { dredging within right whale critical habitat from } \\
\text { December-March must follow the protocol } \\
\text { established within the Early Warning System; whale } \\
\text { observers must be on board to conduct daytime } \\
\text { observations between December and March; during } \\
\text { daylight, operators must take steps to avoid whales; } \\
\text { during evening hours or other times of limited } \\
\text { visibility (fog, sea conditions), the dredge must be } \\
\text { slowed to } 5 \text { knots or less when transiting between } \\
\text { areas if whales have been spotted within } 15 \text { nm of } \\
\text { the vessel's path within the previous } 24 \text { hours; } \\
\text { flexible graduated screens should be used; relocation } \\
\text { trawling guidelines should be followed; lighting } \\
\text { impacts during construction should be minimized } \\
\text { through reduction, shielding, lowering and } \\
\text { appropriate placement; from May-October lighting } \\
\text { on barges operating } 3 \text { nmi from sea turtle nesting } \\
\text { beaches must use the minimum lighting necessary to } \\
\text { comply with USCG and OSHA requirements; species } \\
\text { monitoring may be required }\end{array}$ \\
\hline
\end{tabular}




\begin{tabular}{|c|c|c|c|c|c|}
\hline & $\begin{array}{l}\text { Organisms: } \\
\text { Benthic }\end{array}$ & $\begin{array}{l}\text { Excavation or } \\
\text { otherwise directly } \\
\text { killing species } \\
\text { (crustaceans, } \\
\text { mollusks, and other } \\
\text { marine organisms); } \\
\text { ability of fauna to } \\
\text { recolonize }\end{array}$ & $\begin{array}{l}\text { The effects of } \\
\text { extraction on benthic } \\
\text { communities were } \\
\text { hard to detect after a } \\
\text { number of years; } \\
\text { disruption of } \\
\text { spawning, feeding } \\
\text { and migratory areas }\end{array}$ & $\begin{array}{l}\text { Sand extraction is generally not } \\
\text { permitted within areas that } \\
\text { contain biodiversity of benthic } \\
\text { communities or the presence of } \\
\text { rare species; mining only } \\
\text { allowed in areas that were } \\
\text { previously identified through an } \\
\text { impact assessment }\end{array}$ & $\begin{array}{l}\text { Projects may be required to use environmentally } \\
\text { friendly extraction technologies; screen sizes must be } \\
\text { approved; flexible graduated screens should be used; } \\
\text { species monitoring may be required }\end{array}$ \\
\hline \multirow[t]{3}{*}{ 岃 } & $\begin{array}{l}\text { Commercial } \\
\text { Fisheries }\end{array}$ & $\begin{array}{l}\text { Affect the } \\
\text { suitability of } \\
\text { commercial fishing } \\
\text { grounds as a } \\
\text { habitat; impact } \\
\text { spawning; impact } \\
\text { migration routes }\end{array}$ & $\begin{array}{l}\text { Disruption of } \\
\text { spawning, feeding, } \\
\text { and migratory areas; } \\
\text { risk of collision during } \\
\text { extraction activities }\end{array}$ & $\begin{array}{l}\text { Mining should not influence use } \\
\text { of marine resources }\end{array}$ & $\begin{array}{l}\text { License conditions may specify interactions with } \\
\text { fishing activities }\end{array}$ \\
\hline & Aquaculture & & & & \\
\hline & Oil \& Gas & & & $\begin{array}{l}\text { Sand extraction cannot happen } \\
\text { within } 500 \text { meters of offshore } \\
\text { platforms }\end{array}$ & A setback may be established \\
\hline \multirow{7}{*}{ 岃 } & $\begin{array}{l}\text { Sand \& Gravel } \\
\text { Mining }\end{array}$ & & & $\begin{array}{l}\text { Leases should avoid } \\
\text { overlapping extraction sites; an } \\
\text { area that has been mined once } \\
\text { cannot be mined again }\end{array}$ & $\begin{array}{l}\text { Conditions may specify methods to be used (e.g. } \\
\text { trailing suction) }\end{array}$ \\
\hline & $\begin{array}{l}\text { Pipelines \& } \\
\text { Cables }\end{array}$ & & & $\begin{array}{l}\text { Sand extraction cannot happen } \\
\text { within } 500 \text { meters of pipelines } \\
\text { and cables }\end{array}$ & A setback may be established \\
\hline & Defense & & & & \\
\hline & Shipping & $\begin{array}{l}\text { Dredging required } \\
\text { to maintain } \\
\text { channels }\end{array}$ & $\begin{array}{l}\text { Risk of collision } \\
\text { during extraction } \\
\text { activities }\end{array}$ & & $\begin{array}{l}\text { May specify conditions on vessels to be used; not } \\
\text { allowed to reduce navigation depth }\end{array}$ \\
\hline & Anchorages & Damage to anchors & $\begin{array}{l}\text { Physical occupation } \\
\text { of space during } \\
\text { extraction activities }\end{array}$ & & \\
\hline & Ferry Routes & $\begin{array}{l}\text { Dredging required } \\
\text { to maintain } \\
\text { channels }\end{array}$ & $\begin{array}{l}\text { Risk of collision } \\
\text { during extraction } \\
\text { activities }\end{array}$ & & Not allowed to reduce navigation depth \\
\hline & $\begin{array}{l}\text { Onshore } \\
\text { Transportation }\end{array}$ & & & & \\
\hline
\end{tabular}

- 46 - DRAFT 


\begin{tabular}{|c|c|c|c|c|}
\hline & Civil Aviation & & & \\
\hline \multirow[t]{3}{*}{ 它 } & Wind & $\begin{array}{l}\text { Physical occupation } \\
\text { of space; affect on } \\
\text { substrate; erosion }\end{array}$ & $\begin{array}{l}\text { Sand extraction is generally not } \\
\text { permitted beyond } 12 \text { miles } \\
\text { from the coast, as this area has } \\
\text { been set aside for wind farms; } \\
\text { wind farms will always take } \\
\text { priority seaward of the } 12 \text { mile } \\
\text { zone; sand extraction is not } \\
\text { allowed in a zone with a width } \\
\text { of } 500 \text { meters around offshore } \\
\text { platforms, wind turbines, } \\
\text { cables and pipelines }\end{array}$ & $\begin{array}{l}\text { Offshore wind will not be developed in sand and } \\
\text { gravel mining sites }\end{array}$ \\
\hline & Tidal & & $\begin{array}{l}\text { Mining should not influence } \\
\text { usage of marine resources }\end{array}$ & \\
\hline & Wave & & $\begin{array}{l}\text { Mining should not influence } \\
\text { usage of marine resources }\end{array}$ & \\
\hline \multirow{3}{*}{ 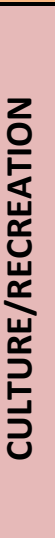 } & $\begin{array}{l}\text { Sites of } \\
\text { Archeological } \\
\text { Significance }\end{array}$ & & $\begin{array}{l}\text { Mining areas (including } \\
\text { mooring areas) should not be in } \\
\text { archeological sites; bottom } \\
\text { disturbing activities (including } \\
\text { anchoring) should avoid } \\
\text { cultural resources by a } \\
\text { minimum distance of } 200 \text { feet; } \\
\text { archaeological avoidance areas } \\
\text { may be designated }\end{array}$ & $\begin{array}{l}\text { Conduct surveys prior to mining to identify } \\
\text { significant resources; if a site cannot be avoided, an } \\
\text { in-depth investigation must be conducted and } \\
\text { submitted to MMS; resources found while extraction } \\
\text { is underway should be reported to MMS, and } \\
\text { operations shall halt until MMS gives further } \\
\text { instructions }\end{array}$ \\
\hline & $\begin{array}{l}\text { Traditional } \\
\text { Rights }\end{array}$ & & $\begin{array}{l}\text { Mining should not influence } \\
\text { usage of marine resources }\end{array}$ & \\
\hline & Views & & & \\
\hline
\end{tabular}




\begin{tabular}{|c|c|c|c|c|c|}
\hline 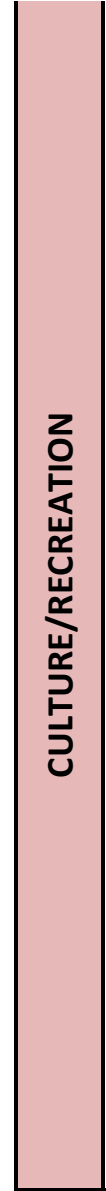 & Recreation & $\begin{array}{l}\text { Affect the } \\
\text { suitability of } \\
\text { commercial fishing } \\
\text { grounds as a } \\
\text { habitat; impact } \\
\text { spawning; impact } \\
\text { migration routes; } \\
\text { alter the aesthetic } \\
\text { value by impacting } \\
\text { water quality, } \\
\text { natural substrate; } \\
\text { denial of access to } \\
\text { resources or } \\
\text { resource site } \\
\text { because of changes } \\
\text { in odor, air quality, } \\
\text { or noise levels at } \\
\text { the site; modify the } \\
\text { educational, } \\
\text { historical, } \\
\text { recreational, and } \\
\text { scientific qualities } \\
\text { of the site; dredging } \\
\text { required to } \\
\text { maintain channels; } \\
\text { beach nourishment } \\
\text { from extracted } \\
\text { materials }\end{array}$ & $\begin{array}{l}\text { Disruption of } \\
\text { spawning, feeding, } \\
\text { and migratory areas }\end{array}$ & $\begin{array}{l}\text { Mining areas should not be in } \\
\text { natural parks or biological } \\
\text { protected areas; mining should } \\
\text { not influence usage of marine } \\
\text { resources }\end{array}$ & $\begin{array}{l}\text { The beach should not be affected from draw-down } \\
\text { into the dredged area (no permanent trapping of } \\
\text { sediments of beach into dredged area) }\end{array}$ \\
\hline 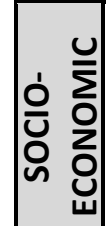 & Jobs & & & & \\
\hline
\end{tabular}




\begin{tabular}{|c|c|c|c|}
\hline $\begin{array}{l}\text { Onshore } \\
\text { Spending }\end{array}$ & $\begin{array}{l}\text { Sediment transport; } \\
\text { storm protection } \\
\text { functions; beach } \\
\text { nourishment from } \\
\text { extracted materials }\end{array}$ & $\begin{array}{l}\text { Based on the onshore/offshore } \\
\text { movement of sand, minimum } \\
\text { distance for sand mining is } 600 \\
\text { meters from the shore; no } \\
\text { dredging if an adjacent beach } \\
\text { already suffers from erosion; } \\
\text { dredging of banks adjacent to } \\
\text { the coastline is not allowed, } \\
\text { except in conditions of high } \\
\text { accretion rates }\end{array}$ & $\begin{array}{l}\text { The beach should not be affected from draw-down } \\
\text { into the dredged area (no permanent trapping of } \\
\text { sediments of beach into dredged area); the supply of } \\
\text { sediments to the coastline should not be affected } \\
\text { (requires an estimation of modified flow and wave } \\
\text { patterns, of changes to sediment transport over } \\
\text { seabed and hence to (coastal) morphology based on } \\
\text { regional and local modeling and existing field data); } \\
\text { any significant changes in wave refraction patterns } \\
\text { altering nearshore waves and hence the alongshore } \\
\text { transport of sediment should be avoided; any } \\
\text { changes to tidal currents close to the coastline } \\
\text { should be avoided; sand bars/banks: minimum depth } \\
\text { based on special studies depending on location; } \\
\text { conduct studies and monitoring of nearshore shingle } \\
\text { bank dredged for beach recharge; conduct studies to } \\
\text { ensure no damage/affect to sand bars/banks } \\
\text { providing storm protection, no significant } \\
\text { interference with nearshore transport process, no } \\
\text { significant changes in nearshore wave climate, and } \\
\text { no change in tidal currents, levels, and tidal prism; } \\
\text { any bars/banks providing protection to the coast } \\
\text { from wave attack should not be damaged/affected }\end{array}$ \\
\hline Tourism & $\begin{array}{l}\text { Used for beach re- } \\
\text { nourishment }\end{array}$ & $\begin{array}{l}\text { No dredging if an adjacent } \\
\text { beach already suffers from } \\
\text { erosion }\end{array}$ & $\begin{array}{l}\text { The beach should not be affected from draw-down } \\
\text { into the dredged area (no permanent trapping of } \\
\text { sediments of beach into dredged area) }\end{array}$ \\
\hline
\end{tabular}

